\section{DISTINCIÓN SOCIAL Y HÁBITAT RESIDENCIAL EN AMÉRICA LATINA ${ }^{1}$}

Sonia Roitman ${ }^{2}$

\section{Resumen}

El aumento de la inseguridad urbana y la sensación de miedo han impulsado el desarrollo de urbanizaciones cerradas en muchas ciudades latinoamericanas. Este modelo residencial ha intentado incluso extender su 'target' a no sólo residentes pertenecientes a los grupos socioeconómicos medio-altos y altos, sino también medio-bajos y bajos. Sin embargo, el presente artículo demuestra cómo vivir en urbanizaciones cerradas continúa estando fuertemente relacionado a la idea de distinción social y estatus. Para esto se analiza cuáles son las características principales de las urbanizaciones cerradas, quiénes son sus residentes, cuáles son sus actividades cotidianas y sus intereses y cómo

\section{SOCIAL DISTINCTION AND RESIDENTIAL HABITAT IN LATIN AMERICA ${ }^{1}$}

Sonia Roitman²

\section{Abstract}

The increase of urban insecurity and the fear of crime have triggered the development of gated communities in Latin American cities. This residential model has even attempted to extend its target not only to upper-middle and high socioeconomic groups, but also to lowermiddle and low income groups. However, this paper shows how living in gated communities is still related to social distinction and status. This article analyses the main characteristics of gated communities, who their residents are, their daily activities and interests as well as 
se relacionan con la ciudad en general. Se concluye que las urbanizaciones cerradas son un importante elemento de distinción social y pertenencia para ciertos grupos sociales.

PALABRAS CLAVE: URBANIZACIONES CERRADAS, DISTINCIÓN SOCIAL Y HÁBITAT RESIDENCIAL.

Fecha de recepción: 07.03.11.

Fecha de aceptación: 10.06.11.

1 El presente artículo da cuenta de los resultados de dos proyectos de investigación. El primero es el proyecto de investigación doctoral cuyos resultados pueden ser revisados más en profundidad en Roitman (2008) y el segundo es un proyecto postdoctoral dentro del grupo 'Entre Espacios' (Instituto de Estudios Latinoamericanos, Universidad Libre de Berlín, 2010-2011).

2 Argentina. Socióloga urbana. Doctora en Planificación Urbana y Regional por la Universidad de Londres. Postdoctorado en Sociología por la Universidad Libre de Berlín, Alemania. Correo Electrónico: soniaroitman@yahoo.com.

18 revista invi № 73 / Noviembre 2011 / Volumen № 26: 17-71 their relation with the city. It is concluded that gated communities are an important element of social distinction and belonging for some social groups.

\section{KEYWORDS: GATED COMMUNITIES, SOCIAL DISTINCTION AND RESIDENTIAL HABITAT.}

Received: 07.03.11.

Accepted: 10.06.11.

1 This article presents the results of two research projects. The first is a doctoral research, Roitman (2008); the second one is a postdoctoral project that is part of the group "Between Spaces" (Institute for Latin American Studies, Berlin Free University, 2010-2011.)

2 Argentina. Urban sociologist. PhD in Urban and Regional Planning, University College London. Postdoctoral fellowship in Sociology at Freie Universitat Berlin. Email: soniaroitman@ yahoo.com

ARTICLE: Social Distinction and Residential Habitat in Latin America 


\section{Introducción: Desigualdades sociales en América Latina}

La región latinoamericana ha logrado una situación económica y política de bastante estabilidad en la última década. Incluso la crisis económica mundial de 2008 tuvo un impacto mucho más moderado en comparación con lo sucedido en otras regiones, debido a la gran inversión en gasto social realizada por la mayoría de los gobiernos de la región, que logró reducir la vulnerabilidad de los grupos más pobres (según la Cepal, el gasto social pasó del 12\% en el período 1990-91 al 18\% en el 2007-08). Por otra parte, durante la última década se ha reducido la pobreza en la región (de $44 \%$ en 2002 a 32\% en $2010^{3}$ ) y se ha avanzado positivamente en el logro de la Meta Al de los Objetivos de Desarrollo del Milenio consistente en reducir la pobreza a la mitad para el año 2015. Esta mejora ha estado relacionada por un lado con el crecimiento económico, pero por el otro lado, con una mejora en la distribución de los ingresos y en varios casos con una mejora salarial. El coeficiente de Gini también ha mostrado significativos avances. Las condiciones de vida han mejorado en la región. La economía creció 6\% en 2010 y se espera que crezca un $4 \%$ en $2011^{4}$. El desempleo se ha

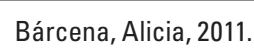

\section{Introduction: Social inequality in Latin America}

Latin America has achieved a stable economic and political situation over the last decade. Even the 2008 financial crisis had a moderate impact in comparison with other regions as a result of massive investment in social spending and welfare, which reduced the vulnerability of the poorest groups (according to ECLAC, social spending increased from $12 \%$ in 1990-91 to $18 \%$ in 2007-08). Furthermore, poverty has decreased in the region during the last decade (from 44\% in 2002 to $32 \%$ in 20103) and there has been progress in relation to achieving the A1 Goal of the Millennium Development Goals, which consists in reducing poverty by a half by 2015. This improvement is linked to economic growth and a better distribution of income and wage increase. The Gini coefficient has also showed progress as life conditions have improved. The economy grew 6\% in 2010 and it is expected to expand by $4 \%$ in $2011^{4}$. Likewise, unemployment fell from $10.5 \%$ in

Bárcena, Alicia, 2011.

Ibid. 
reducido pasando del $10.5 \%$ en 2000 a $7.3 \%$ en $2011^{5}$ y la deuda pública también ha bajado.

A pesar de los avances macroeconómicos, esta región continúa siendo la más desigual del mundo: el 20\% más rico de la población tiene un ingreso 19 veces más elevado que el 20\% más pobre ${ }^{6}$. Debido a esto, la Cepal ha llamado a reducir la desigualdad bajo el lema 'La Hora de la igualdad', a través de un pacto social entre agentes públicos y privados ${ }^{\top}$.

Las diferencias sociales siempre han sido un elemento muy marcado en las sociedades latinoamericanas. La jerarquía social estaba claramente establecida entre los pueblos indígenas anteriores a la "Conquista" y continuó, aun con otras características, con la llegada de los europeos y la expansión de sus imperios. Estas diferencias sociales eran claramente identificables en el espacio social urbano, con la cercanía a la plaza mayor, como el elemento que ponía en evidencia los procesos de distinción social: mientras más cercano a la plaza mayor, más alto se posicionaba ese individuo o familia en la jerarquía social.

Tal como indica Castells ${ }^{8}$, el espacio es una dimensión de la sociedad y expresa los cambios en la estructura social. Así las diferencias sociales se

\section{lbíd.}

Cepal, 2010

Bárcena, Alicia, 2011.

Castells, Manuel, 2001.
2000 to $7.3 \%$ in $2011^{5}$; public debt has also decreased.

Despite this macroeconomic improvement, Latin America is still the most unequal region in the world: the richest $20 \%$ of the population earns 19 times more than the poorest 20\% ${ }^{6}$. As a result, ECLAC has called for reducing inequality under the motto "Time for Equality" through a social contract between public and private actors ${ }^{\top}$.

Social differences have always been a defining element of Latin American societies. Social hierarchy was clearly established among indigenous cultures prior to the "Conquest" and it continued, even if with other features, with the arrival of Europeans and the consequent expansion of their empires. These social differences were clearly identifiable in the urban space, with the proximity to the main square as the element that revealed social distinction processes: the closer to the main square, the higher positioned the individual or family was within the social hierarchy. 
plasman en las ciudades y en los distintos barrios de acuerdo a las diferencias de ingresos y de poder$^{9}$. La distribución de la tierra urbana para diferentes usos se hace de acuerdo a las reglas del mercado y por lo tanto aquellos grupos sociales y aquellas actividades con mayores ingresos son los que pueden acceder a rentas urbanas más elevadas y que por lo tanto se localizan en las mejores zonas de la ciudad. Asimismo, el manejo y distribución del poder influye en la zonificación y planificación urbana. Encontramos así, en lo referente al uso residencial, barrios que albergan principalmente a familias de clase social alta, otros para clases medias (aun cuando dentro de estos hay un gran espectro), y otros para clases bajas. Mientras que las clases media-bajas y bajas habitan generalmente viviendas de interés social o asentamientos informales, las clases media-altas y altas han tendido a concentrarse, en las últimas dos décadas, en las llamadas 'urbanizaciones cerradas'.

Además de expresar los cambios producidos en la estructura social, el espacio urbano también da cuenta de los procesos estructurales que se han desarrollado en América Latina en las últimas décadas. El retiro del Estado, la desregulación económica y las privatizaciones permitieron la llegada de grandes inversiones extranjeras destinadas al desarrollo inmobiliario. También la construcción

$9 \quad$ Marcuse, Peter, 2003.
According to Castells ${ }^{8}$, space is a dimension of society that reflects changes in the social structure. Social differences are expressed in cities and neighborhoods. Since urban land distribution is based on market rules, higher income groups and well-paid activities have access to the best located areas of the city. Likewise, power management and its distribution influence zoning and urban planning. There are neighborhoods that concentrate upper-class families and neighborhoods that concentrate either middleclass groups or lower-class families. While lower-middle and lower income groups generally live in social housing or informal settlements, in the last 20 years upper-middle and high income groups have shown a tendency to live in the so-called "gated communities."

Urban space is not only the mirror of social changes, but also reveals structural processes that have been taken place in Latin America during the last decades. The withdrawal of the state, economic deregulation and privatizations encouraged large foreign investments in real estate. In addition, the

Castells, Manuel, 2001.

Marcuse, Peter, 2003. 
de autopistas privadas dio lugar al desarrollo suburbano y a la expansión de la mancha urbana. De esta forma, algunos autores ${ }^{10}$ hablan de la 'ciudad fragmentada', en referencia a la ciudad latinoamericana a partir de los 70s.

El presente artículo analiza el desarrollo de urbanizaciones cerradas en América Latina, y particularmente en Argentina y México, considerando no sólo las causas por las que estos desarrollos inmobiliarios son elegidos actualmente como lugar de residencia de ciertos grupos sociales, sino también quiénes son sus residentes, cuáles son sus actividades cotidianas y sus intereses y cómo se relacionan con la ciudad en general. Para esto se trabajó con una metodología cualitativa, recolectando información a partir de la realización de 73 entrevistas en profundidad a residentes (hombres y mujeres, jóvenes y adultos) de diferentes urbanizaciones cerradas de Mendoza (Argentina) y Querétaro (México), entre 2003 y 2011.

\section{Urbanizaciones cerradas: ¿qué son?}

Durante las últimas cuatro décadas, la ciudad latinoamericana también ha sufrido un importante proceso de transformación. La ciudad compacta ha dado lugar a una ciudad más fragmentada

10 Ver Borsdorf, Axel, 2003. construction of private highways enabled periurban development and urban sprawl. Thus, some authors ${ }^{10}$ talk about a "fragmented city" when referring to Latin American cities from the 1970s onwards.

This article analyses the development of gated communities in Latin America, especially in Argentina and Mexico. It considers not only the reasons why people choose these housing developments as a place of residence, but also the features of their residents as well as their activities and interests and the way they are related to the city. The paper is based on a qualitative methodology research. Seventy three semi-structured interviews with residents (men, women and children) from different gated communities in Mendoza (Argentina) and Querétaro (Mexico) were carried out between 2003 and 2011.

\section{What are Gated Communities?}

Latin American cities have experienced an important urban transformation over the last four decades. As a result of the growth

10 Ver Borsdorf, Axel, 2003. 
debido al crecimiento de la zonas suburbanas y a la aparición de 'islas urbanas' ${ }^{11}$. Estas islas urbanas están compuestas por conjuntos de equipamientos urbanos que incluyen centros comerciales, instituciones educativas privadas, hospitales privados y urbanizaciones cerradas. Estos espacios insulares reflejan las tendencias homogeneizantes de la globalización que pueden observarse en ciudades alrededor del mundo. El desarrollo de estas 'islas urbanas', y de las urbanizaciones cerradas en particular, profundiza la fragmentación espacial y, tal como afirma Peter Marcuse, las ciudades llegan al extremo de parecer descuartizadas y sus áreas separadas dolorosamente ${ }^{12}$. Por otra parte, las islas urbanas contribuyen a expandir el área urbana, poniendo en evidencia lo que indica Jordi Borja ${ }^{13}$, como un crecimiento horizontal de las ciudades latinoamericanas y un uso ineficiente del suelo con estructuras urbanas de centralidad escasas o débiles.

Si bien las urbanizaciones cerradas no son un elemento nuevo en el paisaje urbano, y algunas ciudades de América Latina ya contaban con este tipo residencial en la primera mitad del siglo $\mathrm{XX}^{14}$, la característica más sobresaliente en la actualidad se relaciona con su desarrollo y establecimiento dentro

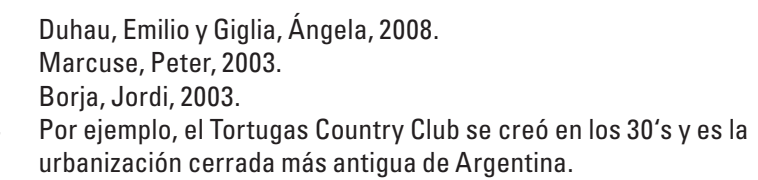

of suburban areas, the former compact city model has given rise to a more fragmented metropolis and "urban islands."11 These urban islands consist of a series of urban amenities such as shopping centers, private education institutions, private hospitals and gated communities. These spaces are the mirror of the homogenizing trends of globalization, which can be observed in cities worldwide. The development of "urban islands", and gated communities in particular, increases spatial fragmentation; in the words of Peter Marcuse, cities seem partitioned and their areas as if they have been painfully pulled apart $^{12}$. Additionally, urban islands contribute to the expansion of the urban area, proving what Jordi Borja ${ }^{13}$ mentions as the horizontal growth of Latin American cities and the inefficient use of land, which result in the emergence of urban structures located away from the city center.

Despite gated communities do not constitute a new element of the urban landscape -this

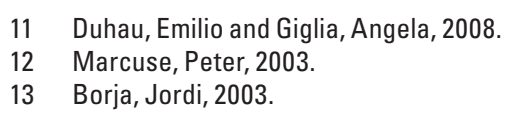

1 Duhau, Emilio and Giglia, Angela, 2008.

13 Borja, Jordi, 2003. 
del mercado inmobiliario como un producto exitoso, y buscado por varios grupos sociales (y aun por aquellos que si bien no pueden acceder a ellos por cuestiones de ingresos insuficientes, buscan todas las formas posibles para acceder a ellos aun si esto significa adquirir grandes deudas financieras).

En este sentido, resulta importante discutir qué son las urbanizaciones cerradas y qué no son o cuáles desarrollos se adecuan o no a las definiciones comúnmente utilizadas. Tal como se manifestó anteriormente $e^{15}$, no existe una definición unívoca de este producto inmobiliario y sus características varían de acuerdo al contexto geográfico en donde se encuentren. Sin embargo, hay elementos comunes a todas las definiciones utilizadas. Se trata de áreas residenciales con un perímetro cerrado por bardas, muros o rejas, con acceso restringido por barreras de seguridad o por guardias que controlan el ingreso de residentes, trabajadores y no residentes. Dentro de esta área residencial, hay viviendas individuales (o en algunos casos de propiedad horizontal), e infraestructura deportiva y social de uso comunitario. Existe un código de construcción y un código de convivencia que rigen la vida cotidiana y son implementados por la asociación de residentes que actúa como el órgano de gobierno del barrio. En muchos casos también existe la figura

15 Roitman, Sonia, 2004.

24 revista invi № 73 / Noviembre 2011 / Volumen $N^{0} 26: 17-71$ residential type already existed in some Latin American cities by the first half of the $20^{\text {th }}$ century $^{14}$ - their most important feature is related to their development and presence in the housing market. These gated communities are seen as a successful product and the goal of an important number of social groups (including those who, despite not having enough financial resources, aspire to live in these spaces even if such effort implies serious financial debts.)

In this sense, it is important to discuss the concept of gated communities and which projects comply with the features according to most common definitions of this residential type. As it was previously mentioned ${ }^{15}$, there is no single definition of this housing project and their characteristics vary according to geographical conditions. However, there are elements that are common to most used definitions. Such elements are walls and fences that surround residential areas, barriers or security guards that restrict access and control the entry of residents, workers and non

14 The Tortugas Country Club was built back in the 30 s and it is the oldest gated community in Argentina.

15 Roitman, Sonia, 2004 
del administrador del desarrollo, quien tiene a su cargo las responsabilidades propias de un alcalde con jurisdicción en un territorio relativamente reducido. Los residentes deben pagar una cuota de mantenimiento mensual o anual que incluye seguridad, jardinería y el mantenimiento de los espacios comunes.

El gran desarrollo de urbanizaciones cerradas durante las dos últimas décadas ha llevado a que se diversifique el producto inmobiliario ofrecido por los promotores inmobiliarios, quienes buscan ampliar su 'target'. De esta manera, si se analiza la oferta de urbanizaciones cerradas en Argentina, se observa que a los pioneros 'countries' o 'clubes de campo' (que ya existían en los 1970s y cuentan con importantes instalaciones deportivas y sociales de uso comunitario) se agregan los 'barrios privados' o 'barrios cerrados', donde se privilegia la seguridad por sobre la oferta de equipamiento comunitario. Este tipo es el que más se desarrolló durante los 1990 s y 2000s. Pero en este periodo también surgieron otros tipos: los 'clubes de chacras' ubicados en zonas más alejadas de la ciudad y que cuentan con amplios lotes; los 'countries náuticos' o 'marinas', los cuales tienen equipamiento deportivo para desarrollar actividades náuticas y se encuentran ubicados junto a un río o lago; los 'countries verticales' o 'torres jardín' que se encuentran localizadas en zonas urbanas más centrales y por lo tanto están construidas verticalmente aumentando la densidad urbana de esas zonas y poseen equipamiento residents. Within this area it is possible to find single housing units (and sometimes high-rise buildings), and sport and social infrastructure for common use. There are construction and coexistence regulations that control daily life; these guidelines are put into practice by the residents' association, which is the governmental entity of the neighborhood. In most cases, there is also a manager emulating the role of a mayor in a small case territory. Residents must pay a monthly or annual fee that covers security and gardening expenses, as well as the maintenance of common areas.

The significant development of gated communities over the last two decades triggered the diversification of the housing market. The analysis of gated communities in Argentina shows that, in addition to the "countries" (which already existed by the 1970s), there are "private neighborhoods" which privilege security over social amenities. This type of gated communities flourished between the 1990s and the 2000s. "Farm neighborhoods" are another different type of housing development that emerged during this period; they are located away from the city and have large plots. "Marinas", located by the 
deportivo de alta calidad que suele incluir piscina gimnasio y cancha de fútbol de salón; y los 'condominios'. Este tipo es el más nuevo, en donde la seguridad es el servicio más importante y el equipamiento de uso comunitario es mínimo. El último tipo es denominado 'mega-emprendimiento' y se trata de un conjunto de barrios cerrados y condominios con importante equipamiento para uso colectivo $^{16}$. Esta tipología de urbanizaciones cerradas es la que se utiliza generalmente para analizar el caso argentino, que constituye uno de los países donde ese producto inmobiliario ha tenido más éxito. Varios de estos tipos (aunque no todos) también se pueden aplicar para el análisis de otros casos latinoamericanos. Sin embargo, es necesario reforzar una vez más que la no existencia de una definición unívoca para el análisis de las urbanizaciones cerradas dificulta la comparación internacional y la aplicación de marcos teóricos y metodológicos que puedan ser generalizables.

Si bien la mayoría de las urbanizaciones cerradas en Argentina está destinada a familias con hijos, los 'condominios' y los 'countries verticales' cuentan también con un importante número de residentes solteros o de parejas sin hijos, dando cuenta de los cambios ocurridos en la composición de los hogares argentinos en las últimas décadas.

16 Para más detalles sobre la tipología de urbanizaciones cerradas en Argentina, ver Roitman, Sonia, 2008. riverside and lakes, have important amenities to practice water activities and sports. "Garden towers" are high-rise buildings and are located in central areas of the city, increasing urban density; they have high quality sport amenities such as swimming pools, gyms and five-aside football. "Condominiums", the newest of all housing developments, privilege security over social amenities. Finally, the "megaproject" is a series of gated neighborhoods and "condominiums" featuring important collective amenities ${ }^{16}$. This typology of gated communities is commonly used to analyze the Argentinean case, which is one of the countries where this housing product has succeeded. Several of these concepts could be used to study other Latin American experiences. However, it is important to mention that the absence of a unique definition regarding gated communities hinders international comparison and the application of common theoretical and methodological frameworks.

Despite most Argentinean gated communities are aimed at families with children, an important number of single people and families

16 For more details regarding gated communities in Argentina, see Roitman (2008). 
En cuanto a su ubicación, la mayoría de las urbanizaciones cerradas (con excepción de los 'countries verticales') se encuentra predominantemente en zonas suburbanas debido a que necesitan una gran extensión de tierra a precios accesibles para los desarrolladores y posteriormente para que sea un producto que aun siendo caro, se considere accesible para los grupos de ingresos medios y altos. A diferencia de lo ocurrido en Estados Unidos, en América Latina se produce una 'suburbanización tardía' de los sectores medios y medios-altos (Torres, 1998), ya que con anterioridad las zonas periféricas eran principalmente las zonas de residencia de los grupos sociales de menores recursos, a través de la autoconstrucción, el desarrollo de asentamientos informales y la construcción de proyectos de vivienda social. En este sentido, resulta interesante el planteo que hace Arizaga cuando se pregunta si este proceso de 'suburbanización de las elites ${ }^{17}$ podría entonces suponer que el suburbio "ha entrado a formar parte de ese 'registro especial de consumo' definido como 'lujo'..."18.

También, en relación a la ubicación, es necesario considerar el impacto ambiental que estos emprendimientos urbanos tienen debido a que hacen uso de parcelas de tierra urbana de grandes dimensiones, por lo cual es frecuente que se cambie el uso del suelo transformando suelo agrícola o incluso

17 Torres, Horacio, 1998.

18 Arizaga, Cecilia, 2003: 14 without children live in "condominiums" and "garden towers", revealing the changes that have taken place in the composition of Argentinean households over the last decades.

As far as location is concerned, most gated communities (except from "garden towers") are located in peri-urban areas, as developers need large portions of land at reduced prices to produce an expensive product that is offered as affordable to middle and high income groups. Since the city outskirts used to be the place of residence of lower social groups through self-helping, the establishment of informal settlements and the construction of social housing, Latin America, unlike the United States of America, experienced a "late peri-urbanization" process of middle and upper-middle income groups. In this sense, it is worth mentioning the reflection of Arizaga on the "suburbanization of elites"17 and the possibility that the suburb may constitute part of this "special type of consumption defined as 'luxury."'18

17 Torres, Horacio, 1998.

18 Arizaga, Cecilia, 2004:14 
áreas ambientalmente protegidas en áreas urbanas. Por ejemplo en el caso del Área Metropolitana de Mendoza, una de las zonas que ha tenido mayor desarrollo inmobiliario, es la zona de mejor calidad de la uva, con lo que se ha perjudicado a la industria vitivinícola ya que la actividad inmobiliaria resulta ser más rentable para los inversionistas. Además, las urbanizaciones cerradas sufren generalmente críticas por parte de los grupos ambientalistas por el uso ineficiente del recurso hídrico que se realiza, principalmente debido a la necesidad de riego de grandes extensiones de áreas verdes (que en algunos casos incluyen campos de golf) y al uso de agua potable en piscinas familiares de uso particular.

Respecto al nivel socio-económico de sus residentes, algunos autores señalan que las urbanizaciones cerradas están diseñadas para grupos medios y principalmente medio-altos y altos ${ }^{19}$, mientras otros autores mencionan la existencia de urbanizaciones cerradas para grupos de ingresos bajos ${ }^{20}$. No obstante, siguiendo la conceptualización aquí desarrollada, parecería difícil que los grupos de ingresos bajos se encontraran en condiciones para solventar el pago de una cuota de mantenimiento mensual o anual, por lo que en muchos casos

19 Caldeira, Teresa, 2000; Svampa, Maristella, 2001; Roitman, Sonia, 2008.

20 Blakely, Edward y Snyder, Mary Gail, 1997.
Also in relation to their location, it is important to think about the environmental impact of these housing developments, as the use of large portions of land implies the transformation of agricultural land, and even environmentally protected areas, into urban land. For instance, in the Metropolitan Area of Mendoza, one of the areas where the best grapes are produced turned out to be the area that presented the highest rates of urban development; as a result, the wine industry has been continuously affected by the real estate activity, which is seen by investors as more profitable. Likewise, gated communities are criticized by environmental groups due to their inefficient use of water resources -to maintain large green areas (including golf courses) and swimming pools.

As for the socioeconomic level of their residents, while some authors point out that gated communities are aimed at middle and upper-middle groups ${ }^{19}$, others identify gated communities aimed at lower income groups ${ }^{20}$. However, it is difficult to think that low income groups can afford to pay monthly or annual

19 Caldera, Teresa, 2000; Svampa, Maristella, 2001; Roitman, Sonia, 2008.

20 Blakely, Edward and Snyder, Mary Gail, 1997. 
podríamos hablar de la existencia de 'pseudo urbanizaciones cerradas', es decir, complejos residenciales que intentan imitar a las urbanizaciones cerradas, que cuentan con un perímetro cerrado y en algunos casos con un guardia de seguridad en la entrada, pero sus viviendas son de una calidad edilicia inferior, de tamaño más reducido, en terrenos más pequeños y con escasos o ningún servicio e infraestructura comunitaria debido a que sus residentes no pueden pagar una cuota de mantenimiento o la misma sólo alcanza para cubrir el pago de un guardia de seguridad. En estas 'pseudo urbanizaciones cerradas' tampoco existe en la práctica una asociación de residentes, ni un administrador y en general tampoco cuentan con un código de construcción o convivencia, y si lo hay, no se encuentra en vigencia. En estos casos, las empresas desarrolladoras tratan de ubicar sus productos en el mercado como una urbanización cerrada, aun cuando no cuenta con todas las características propias de este tipo de oferta inmobiliaria. Este es el caso de las Casas $\mathrm{GEO}^{21}$ de México, que apuntan a grupos medios y medio-bajos. Así Esperanza, quien vive en una urbanización cerrada de Querétaro, México, comentó: “...la realidad es que muchas veces para estar en el fraccionamiento [urbanización cerrada] tienes que partir pues de un nivel medio, porque pues no es asequible a todo mundo, que eso es parte del problema...".

21 Para mayor información ver http://www.casasgeo.com/. fees; therefore, it could be possible to talk about "pseudo-gated communities, that is to say, residential developments that emulate gated communities. This variation of residential type is built within an enclosed perimeter and, in some cases, there are guards watching the main entrance; however, housing is of poorer in smaller land plots with few or inexistent social amenities, as residents either cannot afford to pay maintenance fees or the collected amount only covers security expenses. Additionally, this variation of gated communities lack both an association of residents and a manager in charge of the community and only few of them have in practice construction and coexistence regulations. In these cases, urban developers offer their products as gated communities, even if they do not present the main characteristics of the real ones. Mexico's Casas Geo ${ }^{21}$, a company focused on middle and lower-middle income groups, illustrates this situation: "If you want to live in a gated community, you have to belong to a middle level because not many people have access to gated communities; this is part of the problem..." (Esperanza, a resident of a gated community located in Querétaro, Mexico.)

21 For more information go to http://www.casasgeo.com/ 
Finalmente, es importante mencionar que sería posible hablar de la homogeneidad que tienen los residentes de urbanizaciones como grupo social. Es decir, si bien existen diferencias en cuanto a edades, niveles culturales y educativos, valores, religiones, etc., parecería posible considerar a los residentes de urbanizaciones cerradas como un grupo homogéneo si se lo compara con la estructura social en su conjunto. ¿Cuáles son sus intereses, motivaciones y actividades? y ¿cómo usan la ciudad? son algunas de estas características que los hacen homogéneos y que son discutidas posteriormente en este artículo.

Para resumir, podemos decir que las características predominantes de las urbanizaciones cerradas son:

- Desarrollos cerrados con muros, barreras, rejas y accesos restringidos.

- Incluyen viviendas individuales (y en algunos casos también colectivas) y poseen espacios comunitarios de uso privado.

- Poseen dispositivos de seguridad y servicios de alta calidad.

- Han sido diseñados desde su construcción como espacios cerrados que brindan seguridad a sus residentes y obstaculizan el acceso de los no-residentes.

- Privatizan el uso del espacio público.
Finally, it is worth noting that it could be possible to talk about the homogeneity of residents of gated communities. In this context, although there are differences regarding age, cultural and educational levels, values and religion, all residents of gated communities may be considered as a homogeneous group if compared with the social structure as a whole. What are their interests, motivations and activities? How do they make use of the city? These are some of the characteristics that homogenize this group of people and are further discussed in this article.

In sum, the main characteristics of gated communities are:

- developments surrounded by walls, barriers, fences and restricted accesses

- single housing-units (and multi-unit housing in some cases) with private social spaces

- high quality security devices and services

- built as closed spaces that offer security, thus keeping non residents away from private areas 
- Poseen un código de convivencia y regulaciones sobre la construcción y el diseño de las viviendas.

- Tienen una asociación de residentes que administran el funcionamiento del barrio.

- Son habitados voluntariamente por un grupo social que es homogéneo en relación al conjunto de la estructura social.

- Están ubicados en zonas periféricas (mayoría), pero también en zonas centrales (minoría), lo que contribuye a la cercanía espacial con grupos de diferente nivel socio-económico.

\section{Urbanizaciones cerradas en América Latina}

El desarrollo de urbanizaciones cerradas en América Latina ha estado ligado a diversos factores. En los '50s y '60s, las urbanizaciones cerradas construidas en Buenos Aires (Argentina) se relacionaban con la necesidad de pertenencia, exclusividad y obtención de estatus social por parte de ciertos grupos sociales. Como veremos más adelante, esta última sigue siendo una de las razones más importantes que justifican la multiplicación de este tipo de hábitat residencial. La búsqueda de seguridad y protección para ciertos grupos fue también una razón que justificó su desarrollo, como es el
- they privatize public spaces

- there are coexistence and construction guidelines

- they have a residents' association that manages the neighborhood

- they are voluntarily inhabited by social groups that are homogeneous in relation to the social structure as a whole

- they are located in peri-urban and urban areas, which contributes to the spatial proximity of different social groups

\section{Gated Communities in Latin America}

In Latin America, the development of gated communities has been related to several factors. During the 1950s and 1960s, all gated communities built in Buenos Aires (Argentina) were related to the need to belong, exclusivity and social status. In fact, the quest for higher status is still one of the reasons that justify the expansion of this type of housing. Security and protection are also reasons that boosted the development of gated communities; this is the case of Colonia de los Militares (Colonia 
caso de la 'colonia de los militares' (Colonia General Arce) en El Salvador que buscaba proteger a sus residentes de la guerrilla ${ }^{22}$ o la construcción de complejos residenciales aislados autosuficientes para trabajadores de alto rango de empresas petroleras en Venezuela ${ }^{23}$.

En Lima (Perú) las urbanizaciones cerradas aparecieron como una estrategia de seguridad contra el terrorismo y la violencia ${ }^{24}$, mientras en Brasil fueron una respuesta a la creciente inseguridad urbana y al aumento de la criminalidad en las calles ${ }^{25}$. De la misma manera, la inseguridad urbana fue uno de los factores que impulsó la multiplicación de las urbanizaciones cerradas en Colombia, sumado a la construcción o mejoramiento de autopistas urbanas, el aumento del transporte privado y el hábil manejo de los promotores urbanos para posicionar muy bien a este tipo de vivienda en el mercado ${ }^{26}$. En Argentina, mientras la aparición de la primera urbanización en los '30s estuvo relacionada con la práctica de ciertos deportes elitistas y la vida al aire libre, durante los '90s y 2000s su desarrollo está ligado al aumento de la inseguridad

22 Baires, Sonia, 2003.

23 Bracho de Machado, Diana, Faría Larrazabali, Carmen y Paredes de López, María, 2007.

24 Plöger, Jörg, 2006.

25 Geraiges de Lemos, Amalia, Capuano Scariato, Francisco y Pérez Machado, Reinaldo, 2002.

26 Ortiz-Gómez, Andrés, 2001.
General Arce), located in El Salvador, which was thought to protect residents against the guerrilla ${ }^{22}$ or the construction of self-sufficient, isolated residential complexes for high skilled workers of oil companies in Venezuela ${ }^{23}$.

Gated communities emerged in Lima (Perú) as a security strategy against terrorism and violence $^{24}$. In Brazil, gated communities were the response to the growing urban insecurity and the rise of crime $e^{25}$. Likewise, urban insecurity was one of the factors that increased the expansion of gated communities in Colombia; in addition, urban developers built and improved urban highways, increased private transport and hired clever developers that were able to place in the market this type of housing supply ${ }^{26}$. In Argentina, the first gated community was built in the 1930s and was related to elitist sports and outdoor activities. Most recently, gated communities have been related to the increase of urban

22 Baires, Sonia, 2003.

23 Bracho de Machado, Diana, Faría Larrazabali, Carmen and Paredes de López, María, 2007.

24 Plöger, Jörg, 2006.

25 Geraiges de Lemos, Amalia, Capuano Scariato, Francisco and Pérez Machado, Reinaldo, 2002.

26 Ortiz-Gómez, Andres, 2002. 
urbana $^{27}$. Sin embargo, el presente trabajo trata de ir más allá de estas razones comúnmente argumentadas y plantea que el desarrollo de las urbanizaciones cerradas y el proceso de la elección residencial en particular deben ser vistos como elementos que ayudan a marcar la distinción social.

No hay en América Latina cifras oficiales sobre el número de urbanizaciones cerradas habitadas o en desarrollo que existe en cada ciudad, principalmente porque en la mayoría de los casos, este tipo de hábitat residencial no es considerado como un tipo especial y registrado como tal. Asimismo, el tipo de vivienda (si está dentro de una urbanización cerrada o no) no está tampoco contemplada como una opción en la mayoría de los censos nacionales. Debido a esto, los datos sobre urbanizaciones cerradas que se tienen provienen de la combinación de datos de los gobiernos locales (principalmente de catastro) y de la información recolectada por investigadores a través de su trabajo de campo. Por ejemplo, en el caso de México, ya había 20 urbanizaciones cerradas en Guadalajara antes de $1994^{28}$, unos 12 casos en Toluca y una situación similar en Puebla ${ }^{29}$. A partir del año 2000 se han multiplicado en muchas ciudades mexicanas, apareciendo como 'la única opción

27 Roitman, Sonia, 2008

28 Cabrales Barajas, Luis Felipe y Canosa Zamora, Elio, 2001.

29 Rodríguez Chumillas, Isabel y Mollá Ruiz-Gómez, Manuel, 2002. insecurity ${ }^{27}$. However, this article goes beyond these reasons and poses the assumption that the development of gated communities and residential choice should be seen as elements that determine social distinction.

Since gated communities are not regarded as a special type of housing and considered like this in the urban construction records, there are not official figures about their number in Latin America. Additionally, most of national censuses do not consider housing units according to whether they are located or not in within gated communities. As a result, all information regarding gated communities is retrieved from local governments and field researchers. For instance, in the case of Mexico, there were 20 gated communities in Guadalajara before 199428. Toluca (and likewise Puebla) had 12 gated communities ${ }^{29}$. From 2000 onwards, these projects began to spread in a large number of Mexican cities. There are more than a hundred gated communities built in northern border cities where they are considered as "the

27 Roitman, Sonia, 2008

28 Cabrales Barajas, Luis Felipe and Canosa Zamora, Elio, 2002.

29 Rodríguez Chumillas, Isabel and Mollá Ruiz-Gómez, Manuel, 2002. 
residencial' en algunas ciudades fronterizas del norte mexicano donde hay ya más de un centenar de urbanizaciones cerradas. En el caso de Tijuana, estos desarrollos inmobiliarios están relacionados con exclusividad social, al encontrarse ubicados en las zonas montañosas periféricas con difícil (y por lo tanto más exclusivo) acceso desde el centro de la ciudad ${ }^{30}$. La Ciudad de México, sobre todo en la zona de Santa Fe, también ha experimentado un gran crecimiento de este tipo de vivienda.

El Salvador cuenta con varias urbanizaciones cerradas $^{31}$, al igual que Colombia ${ }^{32}$ y Ecuador. En el caso de la capital ecuatoriana, Borsdorf ${ }^{33}$ menciona que ya en 2002 había 27 urbanizaciones cerradas en Quito. En Montevideo (Uruguay) había ya 10 urbanizaciones cerradas en $2003^{34}$.

En el caso de Chile, según la literatura, este tipo de residencia también ha tenido muy buena aceptación dentro de ciertos grupos sociales en las ultimas dos décadas. Ya en el año 2000 había en Santiago más de 700 urbanizaciones cerradas $^{35}$ y casi unas 300 en el Área Metropolitana de Valparaíso en $2007^{36}$. En todo caso, estas cifras deben tomarse con precaución, ya que como se explicó anteriormente,

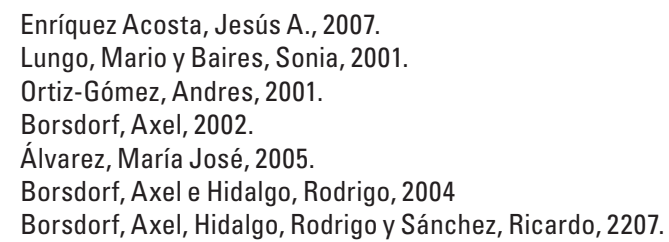

only residential option." In Tijuana, these housing developments are related to social exclusiveness, as they are located in periurban mountain areas that are difficult to reach from downtown (and therefore more exclusive) $)^{30}$. Mexico City, especially Santa $\mathrm{Fe}$ area, has experienced the expansion of this type of housing. There are also gated communities in El Salvador ${ }^{31}$, Colombia ${ }^{32}$ and Ecuador. According to Borsdorf ${ }^{33}$ there were 27 communities in Quito (Ecuador) by 2000. Likewise, Montevideo had 10 of these housing developments in $2003^{34}$.

In the case of Chile, according to the literature, this type of housing has succeeded among certain social groups over the last two decades. By 2000, there were more than 700 gated communities in Santiago ${ }^{35}$ and about 300 developments in Valparaiso back in $2007^{36}$. However, these figures should be carefully taken into consideration as, according to the

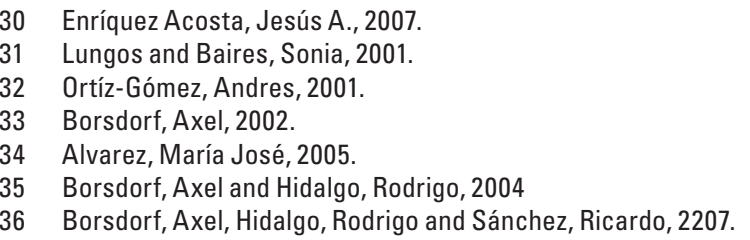


debido a la existencia de múltiples definiciones de lo que se entiende como urbanización cerrada, muchos de los casos chilenos serían considerados simplemente como edificios en propiedad horizontal en otros países latinoamericanos, mientras que otros serían considerados como bloques de vivienda social y no urbanizaciones cerradas per se. Brasil y Argentina son los países donde este fenómeno se encuentra más extendido. Es difícil estimar el número de urbanizaciones cerradas en las ciudades grandes e intermedias de Brasil; sin embargo, la gran cantidad de trabajos de investigación sobre este tema, que toman como objeto de estudio estas ciudades, sería un indicador de la relevancia que han adquirido en el paisaje urbano ${ }^{37}$. Para el caso de Argentina, si bien no hay tampoco datos precisos, es posible estimar que solamente en el Área Metropolitana de Buenos Aires hay por lo menos 500 urbanizaciones cerradas, mientras que en las ciudades intermedias de Rosario, Córdoba y Mendoza también hay un considerable número de este tipo de hábitat residencial.

37 Caldeira, Teresa, 2000; de Lima Ramírez, J.C. y Ribeiro Soares, B., 2002; Geraiges de Lemos, Amalia; Capuano Scariato, Francisco y Pérez Machado, Reinaldo, 2002; Rodrigues Joares, Paulo R., 2002; Rodrigues, Silvia, 2006. multiple definitions of gated communities, many of Chilean cases would be regarded as horizontal property or social housing and not gated communities.

Gated communities have become massive in Brazil and Argentina. It is difficult to calculate the number of projects in large and intermediate cities in Brazil; however, the great number of articles on this topic reveals the importance of gated communities within the urban landscape ${ }^{37}$. In the case of Argentina, although there is no accurate information about gated communities, it is possible to estimate that there are at least 500 projects in the Metropolitan Area of Buenos Aires; additionally, an important number of communities have been built in intermediate cities such as Rosario, Cordoba and Mendoza.

37 Caldeira, Teresa, 2000; de Lima Ramírez, J.C., and Ribeiro Soares, B., 2002; Geraiges de Lemos, Amalia; Capuano Scariato, Francisco and Pérez Machado, Reinaldo, 2002; Rodrigues Joares, Paulo R., 2002; Rodrigues, Silvia, 2006.

revista invi № 73 / November 2011 / Volume № 26: 17-71 


\section{Factores que influyen en la decisión de localización residencial}

Según la literatura, las principales razones por las que la gente elige vivir en una urbanización cerrada son:

a) Globalización económica, aumento de inversiones extranjeras directas y aumento de las desigualdades sociales urbanas ${ }^{38}$.

b) Retiro del Estado de la provisión de servicios sociales básicos (en este caso, principalmente seguridad) y aumento de la inseguridad urbana y la provisión de seguridad privada ${ }^{39}$.

c) Aumento de la sensación de inseguridad ${ }^{40}$.

d) Búsqueda de un mejor estilo de vida (mayor contacto con la naturaleza y alejada del caos de la ciudad $)^{41}$.

e) Búsqueda de mejores servicios y preferencias económicas relacionadas con los precios de la tierra y estabilidad en los precios de los inmuebles ${ }^{42}$.

38 Sassen, Saskia, 1991; Svampa, Maristella, 2004

39 Caldeira, Teresa, 2000; Arizaga, Cecilia, 2005.

40 Helsey, Robert W.y Strange, William C., 1999.

41 Svampa, Maristella, 2001; Cabrales Barajas, Luis Felipe y Canosa Zamora, Elio, 2001

42 Webster, Chris, 2001; Coy, Martin y Pohler, Martin, 2002.

\section{Factors Influencing Residential Localization}

According totheliterature, themain reasonswhy people choose to live in gated communities are:

a) economic globalization, increase of foreign direct investments and increase of urban social inequality ${ }^{38}$

b) the withdrawal of the state from the provision of basic social services (in this case, mainly security), the increase of urban insecurity and private security services ${ }^{39}$

c) the increase of the sense of insecurity and fear of crime $^{40}$

d) search for a better lifestyle (more contact with nature and places located away from the (ity) $)^{41}$

e) search for better services and economic preferences related to the price of land and housing ${ }^{42}$

\footnotetext{
Sassen, Saskia, 1991; Svampa, Maristella, 2004. Caldeira, Teresa, 2000; Arizaga, Cecilia, 2005. Helsey, Robert W. and Strange, William C., 1999.

1 Svampa, Maristella, 2001; Cabrales Barajas, Luis Felipe and Canosa Zamora, Elio, 2001.

42 Webster, Chris, 2001; Coy, Martin and Pohler, Martin, 2002.
} 
f) Búsqueda de sentido de comunidad ${ }^{43}$.

g) Búsqueda de homogeneidad social ${ }^{44}$.

h) Búsqueda de mayor estatus y distinción social dentro de determinados grupos sociales ${ }^{45}$.

Sin embargo, cuando los residentes de urbanizaciones cerradas son consultados sobre las motivaciones que los llevaron a vivir en ellas, no todas estas razones citadas por la literatura son mencionadas, mostrando la brecha que existe entre la justificación explícita que se da sobre este proceso de vivir en 'lugares enrejados' y las razones más profundas que se relacionan con la necesidad de pertenecer y de lograr distinción social.

La primera razón esgrimida al hablar de urbanizaciones cerradas con sus residentes es la inseguridad. Esta justificación aparece no solamente como la más difundida entre los residentes (sin importar si estos han sido o no víctimas de delitos o crímenes) sino como la razón más aceptada socialmente. Y esta razón se da no solamente en ciudades con altas tasas de delincuencia y marginalidad, sino también en ciudades consideradas seguras.

Alfonso $^{46}$ (residente en una urbanización cerrada de Mendoza, Argentina) explicó: “...trabajamos

43 Wilson-Doenges, Georgina, 2002.

44 Svampa, Maristella, 2001; Arizaga, Cecilia, 2005

45 Blakely, Edward d. y Snyder, Mary Gail, 1997; Caldeira, Teresa, 2000; Svampa, Maristella, 2001.

46 Los entrevistados tienen nombres falsos en todo el desarollo del artículo para protejer sus identidades. f) search for sense of community ${ }^{43}$

g) search for social homogeneity ${ }^{44}$

h) search for a higher social status and social distinction among certain social groups ${ }^{45}$

However, when asked about the factors that led them to live in gated communities, residents mentioned not all the reasons presented in the aforementioned list. In this way, the gaps between the explicit reasons people give to living in 'fenced places' and deeper reasons related to the need to belong and social distinction is revealed.

Insecurity is the first reason given by residents when asked about gated communities. This reason is not only the most common among people (regardless if they have been victim of crime or not), but also it is the most socially accepted. This reason is shared by people living in cities with high crime and marginality rates and also by people from 'secure' cities.

43 Wilson-Doenges, Georgina, 2002

44 Svampa, Maristella, 2001; Arizaga, Cecilia, 2005.

45 Blakely, Edward d. and Snyder, Mary Gail, 1997; Caldeira, Teresa, 2000; Svampa, Maristella, 2001. 
los dos [él y su esposa] con mucha carga horaria, estoy mucho tiempo fuera de la casa y los chicos se quedan mucho rato solos, hay una señora que hasta el mediodía está, pero después hasta las seis de la tarde que viene Mari [su esposa], yo llego a las ocho, todos ese tiempo estaban solos los chicos... y bueno, buscamos algo seguro porque ya teníamos antecedentes de robo... al del medio [su hijo] le robaron la bicicleta y lo golpearon donde vivíamos antes...".

Por su parte, Juana, quien vive en una urbanización cerrada de Querétaro, México, manifestó que si bien ellos eligieron ese lugar para vivir ahí hace 15 años por su ubicación cercana a comercios y con buenas vías de acceso, la seguridad es ahora un elemento muy importante: "aquí conozco tres familias que han venido a vivir a este fraccionamiento, a esta colonia, por secuestros en otras ciudades".

Estefanía (residente de una urbanización cerrada de Querétaro, México) detalló su situación personal: "nosotros tenemos la gran desventaja de que Jorge es hijo único... no podía salir a jugar a la calle porque era un lugar abierto, era una calle con mucha pendiente y de repente se nos complicaba mucho la cuestión de la seguridad con él, la educación de los niños [del barrio] también era distinta, a lo mejor eran niños que ellos sí pasaban mucho
Alfonso ${ }^{46}$ (resident of a gated community located in Mendoza, Argentina) explained: "We both [he and his wife] have a high workload. I'm away from home most of the time and the kids are at home alone a lot; there is a lady in the house until noon, but then the kids are left alone until six in the evening, when Mari [his wife] arrives at home; I get home at 8pm... and well, we looked for something safe because we already had a history of theft... One of my kids was beaten and his bike stolen where we previously lived..."

Juana, who has been living in a gated community in Querétaro (Mexico) for 15 years, said that, although they decided to live in that community because of its proximity to shops and the availability of good roads connections, security has turned out to be an important element: "I know three families here who chose this gated community as a place of residence due to kidnappings in other cities."

Estefania, a resident of a gated community located in Querétaro, gave her personal experience: "We had a great disadvantage,

46 Interviewees are given false names here and throughout the whole article to protect their identities.

7103 Revista Invi 73 Interior indb 38 
tiempo en la calle, entonces no nos agradaba como el medio para Jorge, entonces decidimos vender esa casa y empezamos a buscar por esta zona que es la que nos es más cómoda por distancias". De esta forma vemos que si bien la seguridad aparece fuertemente en los discursos de los residentes, otros elementos también son tomados en cuenta, tal como menciona Estefanía, ya que el nivel educativo de los otros niños del barrio y el análisis del tipo de socialización que sus padres querían para Jorge fueron algunas de sus motivaciones para cambiar de lugar de residencia.

Por otra parte, en el caso de las urbanizaciones cerradas de México, en muchos casos sus residentes son personas originarias de la Ciudad de México, que deciden localizarse en otras ciudades intermedias de los alrededores (como es el caso de Querétaro) por cuestiones de seguridad y llevan con ellos el modelo de 'vivir en una urbanización cerrada' (o 'vivir en un fraccionamiento', tal como son conocidos en México), aun cuando se localizan en ciudades consideradas 'seguras' y justamente elegidas por este motivo. Así, una entrevistada explicaba: “...me vine de México, pues porque México ya sabes, el caos, entonces vine buscando [urbanizaciones cerradas] en Querétaro y Querétaro se me hizo un lugar muy bonito, muy tranquilo y buscando which is that Jorge, our only child, was not able to play outdoors because the area outside our home was an open space, it was a sloped street and his security was a matter of concern to us. In addition, Jorge and his friends had different education levels and maybe those kids spent most of the time out on the streets, and as we did not want our child to live in such environment, we decided to sell our house and started looking for [a house] in this area, which is convenient for us for distance reasons." In this way, it is possible to see that residents mention elements other than security, as in this case, in which the aspired education and socialization for Jorge were the reasons that made Estefania's family to change their residential location.

In Mexico, some residents of gated communities are people from Mexico City who decided to move to intermediate nearby cities (like Querétaro) for security reasons. In this process, people take with them the idea of "living in a gated community" even if they move to secure cities: "I moved from Mexico City to here 
encontré $\mathrm{EC}^{47}$ y fue lo que más me gustó" (Paulina, residente en una urbanización cerrada de Querétaro, México).

Aun en los casos en que la seguridad no fue el elemento determinante en la decisión de vivir en una urbanización cerrada, ésta siempre aparece mencionada por los residentes como una de las ventajas de este tipo residencial: "...las ventajas son tener espacio abierto; yo creo que también la seguridad, la extensión de terreno, las áreas verdes desde luego que son importantes, nosotros les sacamos mucho provecho con los niños" (Andrés, residente en una urbanización cerrada de Querétaro, México).

José (residente de una urbanización cerrada de Mendoza, Argentina) comentó cuáles fueron las razones involucradas en la selección de su lugar de residencia: "en primer lugar buscar un espacio que guardara las características de, no solamente de seguridad, si bien la seguridad es importante, te diría que lo que primó... fue tratar de buscar un espacio urbanístico que permitiera que uno pueda desarrollarse con las características con la cual [sic] crecimos nosotros, digamos, la idea de barrio, con espacios abiertos, con el patio típico, este... con la reunión de vecinos, digamos, poder disfrutar de esos espacios que, que es muy difícil conseguirlos

47 Se consignan sólo las iniciales del nombre de la urbanización cerrada para mantener su anonimato. Esto se aplica a todas las urbanizaciones cerradas mencionadas en este texto. because it is a chaotic place and I was looking for gated community in Querétaro, which is a really nice and quiet place, this is how I found EC ${ }^{47}$ " (Paulina, resident of a gated community in Querétaro, Mexico.)

Security, even in cases where it was not the reason that governed the decision of living in gated communities, is always mentioned by residents as one of the advantages of this residential type: "The advantages of living in a gated community are the possibility of having open spaces and I think that also security, the extension of land and the green areas are important, the kids really take advantage of these features" (Andrés, resident of a gated community located in Querétaro.)

Jose (who lives in a gated community in Mendoza) commented the reasons that made him choose their place of living: "Firstly, it was the search for a place that featured not only security, which is important, but also an area that enabled the development of outdoor activities... a place like "the neighborhood", open spaces, meeting neighbors, and enjoying

47 Initials were used to protect the anonymity of gated communities. 
hoy... y después bueno, la seguridad, obviamente y bueno, también en tercer lugar te diría una cuestión de inversión". Aquí aparece no solamente la idea de la seguridad como factor explicativo, sino la necesidad de recuperar al barrio como un espacio de socialización y por otra parte, la idea de la vivienda como una inversión, es decir, como uno de los bienes privados más importantes y valiosos que puede tener un individuo o grupo familiar.

En relación a la socialización, las ideas de pertenencia y de homogeneidad social también aparecen mencionadas por los residentes. En el caso de la homogeneidad social, Samuel (residente de una urbanización cerrada de Mendoza, Argentina) dijo: “...para algunos pienso que lo buscan, como algunos buscan determinadas escuelas para sus hijos, no porque sean mejor escuela, sino porque tiene un nivel social determinado, no es mi caso, pero sé de muchos que lo piensan así..." . Clara, quien vive en una prestigiosa urbanización cerrada de Mendoza, se refirió a los motivos para vivir ahí: "lo que yo escucho, pero que no es mi caso, [es] que es más seguro y después pertenecer a ciertos grupos, identificarse... Mirá, me pasa algo sintomático: Yo puedo decir que vivo o en Godoy $\mathrm{Cruz}^{48}$ o en P., Si digo en Godoy Cruz, soy una chanta y si digo en P. soy la distinta, incluso cuando vos lo decís en those places... places like these are difficult to find; then security obviously and then, also, in third place, the issue of [being] an investment... "In this case, the concept of security goes along the need of recovering the neighborhood as a space for socialization; likewise, housing is seen as an investment, which is one of the most valuable private assets that a family or an individual may have.

As far as socialization is concerned, the ideas of belonging and social homogeneity are also mentioned by residents. In the case of social homogeneity, Samuel (resident of a gated community in Mendoza) said: "I think some people search for this like... some seek certain schools for their children, not because they are better schools, but... because they have a particular social status, this is not my case, but I know many who think like this..." Clara, who lives in a prestigious gated community of Mendoza, commented on the reasons to live there, "what Ihear, but it is not my case, [is] that it is safer, and then to belong to certain groups, to identify with them... Look, something

48 Godoy Cruz es una de las seis municipalidades que conforman el Área Metropolitana de Mendoza. P. es una urbanización cerrada ubicada en la municipalidad de Godoy Cruz. 
determinados grupos, yo en eso tengo mucho cuidado porque sé que da mucho impacto, es como que, es una persona rica y rica igual feliz, igual sin problemas, y eso también desata un poco de envidia, y eso que te ven distinta".

Aparece así (consciente o inconscientemente, asumida como propia o asociada a los demás pero no a uno/a mismo/a) la idea de distinción, de verse o mostrarse distinto o distinta. Caldeira ${ }^{49}$ explica que la construcción de símbolos de estatus es un proceso que permite elaborar las diferencias sociales y crear los mecanismos que permiten reforzar la distancia social y la desigualdad. Así los muros perimetrales de las urbanizaciones cerradas y sus dispositivos de seguridad son el primer elemento para remarcar la distancia social.

Esperanza (residente de la que es considerada por algunas personas 'la mejor urbanización cerrada de Querétaro') comentó: "Mucha gente vive aquí porque le encanta decir vivo en EC, o sea que me vean el coche, que tenemos un vecino con el RollsRoyce, el coche de no sé cuánto, el coche de no sé qué, ahí está el terreno pa' [sic] que jueguen sus hijos a un lado y los seis guaruras ${ }^{50}$ afuera y es como 'que me vean'. Dices 'oye, pues aguas', o si llega un Ferrari. Siento que estos tiempos son tiempos de

49 Caldeira, Teresa, 2000

50

'Guaruras' son los guardias personales privados en México. symptomatic happens to me: I can say I live in Godoy Cruz ${ }^{48}$ or in P. If I say in Godoy Cruz I'm an unreliable and lazy person and if I say in P. I am special. Also I am very careful to say so within certain groups because I know that it has quite an impact, it is like it's a rich person and rich equals happy, equals without problems, and this also unleashes a bit of envy, and that they see you as being a bit different."

Theidea of distinction, of seeing oneselfdifferent from or of appearing different or distinct thus emerges (consciously or unconsciously, assumed as one's own or... associated with others but not oneself.) Caldeira ${ }^{49}$ says that the construction of status symbols is a process that enables the creation of social differences and mechanisms that increase social distance and inequality. In this sense, the perimeter walls and security devices of gated communities are the first element to reinforce social distinction.

Esperanza (resident of what is considered by some people the 'best gated community of Querétaro') commented: "Many people live

48 Godoy Cruz is one of the six municipalities that constitute the Metropolitan Area of Mendoza. P is a gated community located in Godoy Cruz.

49 Caldeira, Teresa, 2000. 
crear conciencia porque me parece que detrás de esas actitudes estamos siendo muy agresivos con el entorno, pero hay gente que le gusta eso: 'yo soy fulano y vivo aquí y hago esto'...”. Así, Víctor, residente de una urbanización cerrada de Mendoza, dijo: 'Yo no me mudé a P. por estatus social...", pero posteriormente, durante la misma entrevista, manifestó: "Vivir en P. es un signo de mi éxito profesional como abogado".

En este sentido, el lugar de residencia muestra el éxito profesional y por lo tanto aun en condiciones de crisis (pérdida del empleo, por ejemplo), muchas de estas familias realmente deben luchar para seguir perteneciendo a ese grupo. Soledad (residente de una urbanización cerrada de Mendoza) relató su experiencia como no-mendocina: “... lo que pasa [es] que la apariencia acá en Mendoza es fundamental... yo veo gente que quizás está en otra situación, vos viste que tienen, aparentan como que tienen más que cualquiera... pero no... Acá me di cuenta que mucha gente no tiene [tanto dinero], no paga las expensas... pero vive en P., tiene la $4 \times 4$ y va a colegios privados, pero no paga ni el colegio y vive como un duque".

Es interesante también el papel que juega el consumo y la necesidad de mostrar poder económico a través del consumo de bienes y servicios. Tal como explica Bourdin, en la sociedad actual, el consumo se ha transformado en "un valor en sí mismo", "una

ARTíCULO: Distinción social y hábitat residencial en América Latina

/ Sonia Roitman here because they love saying 'I live in $E C$ '... or that people see their car, or that we have a neighbor with a Rolls Royce, the car of so and so,... there's the site for their children to play on one side and the six guaruras ${ }^{50}$ outside and it's like 'hello! Look at me." I think these are times to raise awareness because behind these attitudes we are being very aggressive with the environment, but some people like that: 'I am so and so and I live here and I do this and that'..." Victor (resident of a gated community in Mendoza) for example said, "I did not move to $P$. because of social status..." but later in the same interview he claimed: "Living in P. is a sign of my professional success as a lawyer."

In this sense, the place of residence is the mirror of professional success and, even in crisis (like the loss of job), many of these families struggle to continue in this group. Soledad shares her experience as a foreigner living in Mendoza: "Appearance is essential in Mendoza... I see people that pretend they are richer than anyone, but this is not the case... I realized that many people do not have enough money and, despite not paying their expenses, they live in $P$, have the four wheel drive off-road and attend

50 Guaruras are private personal bodyguards in Mexico. 
visión del mundo ampliamente compartida"51. Según este autor, los individuos estamos obligados a "tomar posición", es decir, a definir nuestro lugar en una configuración social y esto es, en parte, realizado mediante el consumo. Juana (de Querétaro, México) comentó al respecto: “...el vivir en un fraccionamiento, o sea, yo vivo acá y este ehhh... no estoy de acuerdo en muchas cosas, por ejemplo..., al vivir en privado los carros, el tener una, dos muchachas, dos chicas que te ayuden [con la limpieza], ese no es mi caso, pero... la mayoría de un fraccionamiento tiene chofer, la comodidad de tener otros servicios que a la puerta de tu casa te traigan... no sé, el agua, no sé, si tener chofer, tener más, si, si a veces te encierra en muchas comodidades".

Antonieta vivía en una urbanización cerrada de Mendoza, pero debido a 'problemas económicos', después de construir la casa y vivir en ella durante dos años y medio, se vieron obligados a vender su casa y mudarse a un barrio de un nivel socioeconómico más bajo ubicado en una zona antigua de la ciudad. Ella describió la situación: "en ese momento [cuando compraron el lote] realmente estábamos en buena... no en buena posición, pero teníamos un buen pasar, teníamos buen trabajo... [compramos el lote]... Y después, vendimos nuestra casa, alquilamos, y en dos años ya estábamos viviendo [ahí]... por supuesto que nos fuimos sin

51 Bourdin, Alain, 2007: 52. private schools; however, they do not pay the tuition fees and live like the royal family."

It is interesting to note the role played by consumption and the need of demonstrating economic power through the acquisition of goods and services. In the words of Bourdin, in today's society, consumption has become a "value in itself" and a "widely shared vision of the world"51. According to this author, people are forced to define their place within a social configuration; consumption plays an important role in this process. Juana (from Querétaro, Mexico) mentioned: “... living in a gated community, ehh I mean I live here [but]... I do not agree on many things, for example... to live in a private place, the cars, having one or two maids, two girls that help you [with the housework], that is not for me, but... the majority within a gated community have a driver, the convenience of other services, things brought to your doorstep... I don't know, the water, I don't know if having a driver, having more... sometimes it encloses you in many conveniences."

Antonieta used to live in a gated community in Mendoza but due to financial problems,

51 Bourdin, Alain, 2007: 52. 
terminar [la construcción de la casa]... La hemos disfrutado [la casa]... Pero después, lo que pasa es que a medida que la situación nos fue 'apretando', tuvimos que... mi hijo, que tenía... alquilaba un departamento, también se vino a vivir a mi casa de P.". Posteriormente, en la entrevista Antonieta agregó: "cuando me fui a vivir allá [la urbanización cerrada], toqué el cielo con las manos...". La narrativa de esta mujer refleja las estrategias familiares para lograr la casa tan deseada y la lucha por 'resistir la caída'.

Arizaga $^{52}$, en su análisis de urbanizaciones cerradas de Buenos Aires (Argentina), comenta la necesidad de muchos residentes de construir un grupo de pertenencia y así utilizar la residencia como el elemento de distinción y pertenencia. En este sentido, Svampa ${ }^{53}$ argumenta que la segregación espacial mediante el encierro en urbanizaciones cerradas es una de las estrategias desarrolladas por los 'ganadores' del sistema, es decir, por aquellos que han sabido adaptarse a las nuevas condiciones económicas y laborales. El ejemplo de Antonieta muestra una situación de imposibilidad de mantener ese 'nivel', que ella misma en cierta forma reconoce: "...nosotros éramos de los de la clase media que con sacrificio pudimos hacernos lo que nos hicimos, ¿no es cierto? Pero, por supuesto, yo

52 Arizaga, Cecilia, 2005.

53 Svampa, Maristella, 2001. after two and a half years she found herself forced to sell her house and moved to a lower socioeconomic neighborhood located in the old area of the city. Commenting on that situation she said: "At the time [when they bought the plot] things were really good... we were not in a good position, but we were ok, we had good jobs... [we bought the plot]... And then, we sold our house, we rented, and within two years we were living [there]... of course we left without finishing [building the house]... We have enjoyed [the house]... But then what happened is that as the situation was becoming more difficult, we had to... my son, who was... renting an apartment, also came to live in my house in P." Later in the interview Antonieta added: "When I moved in there [the gated community], I touched the sky with my hands..." This lady's narrative reflects the family strategies to achieve the so desired house and the struggle to 'resist the fall.'

In her analysis of gated communities in Buenos Aires, Arizaga ${ }^{52}$ talks about the need of many residents of constructing a belonging group and use the residence as a distinction

52 Arizaga, Cecilia, 2005 
sé que hay gente que tiene mucho dinero, como hay gente que no lo tiene...".

La idea del éxito profesional y la distinción también aparece fuertemente marcada por las estrategias de marketing de las empresas desarrolladoras que ofrecen viviendas en urbanizaciones cerradas bajo los siguientes mensajes: 'Residencial del Parque, casas para futuros triunfadores', 'El Campanario: la vida te sonríe', 'Imagínese... La vida desde una perspectiva diferente... Imagínese... viviendo inmerso en la naturaleza... abriendo su ventana y deleitándose con ese verde que siempre quiso tener sentado en su jardín contemplando las montañas" ${ }^{24}$. Todos estos mensajes reflejan algunas de las razones por las que las urbanizaciones cerradas son buscadas como una opción residencial, tal como se mencionó al inicio de esta sección.

Habiendo analizado cuáles son las razones que llevan a ciertas personas a elegir vivir en urbanizaciones cerradas, es necesario analizar las características propias de sus residentes que los identificarían como un grupo social determinado y en este sentido cuáles son sus actividades, intereses y valores y cuál es la concepción de ciudad que tienen.

54 Los dos primeros mensajes corresponden a publicidad en la vida pública de dos urbanizaciones cerradas en Querétaro, México. El tercer mensaje fue extraído de la página de internet del grupo desarrollador de La Vacherie (Mendoza, Argentina), disponible en http://elinmobiliario.com/desarrollos/argentina/mendoza/ countries/grupo_dinosaurio_-_mendoza/la_vacherie_-_country_golf 315.html (consultado 19/06/2011). and belonging element. In this sense, Svampa ${ }^{53}$ argues that spatial segregation by the confinement in gated communities is one of the strategies developed by the 'winners', who are those who succeeded in adapted to new work and economic conditions. The experience of Antonieta illustrates the impossibility to remain in a determined "level" as she somehow recognizes: "we are a middle-class family and thanks to our effort we were able to become what we are now. However, it is clear that there are people who have large amounts of money and there are people who do not" (Antonieta.)

The concepts of professional success and distinction are strongly influenced by the marketing strategies of developers who offer houses in gated communities with messages such as "Residencial El Parque, houses for future winners"; "El Campanario: Life smiles at you"; "Think about life seen from another perspective, think about living surrounded by nature, opening your window and enjoying

53 Svampa, Maristella, 2001. 


\section{¿Quiénes son los residentes de urbanizaciones cerradas?}

Si bien las urbanizaciones cerradas tienen características locales en cuanto a que responden a las necesidades de la población local, a sus intereses y gustos, también son parte de una tendencia global que es impulsada por los desarrolladores urbanos a través de campañas de marketing, tal como se explicó en la sección anterior. En muchos casos un mismo diseño urbano es replicado en diferentes países, con una gran predominancia de modelos llevados a América Latina desde Estados Unidos, que no sólo incluyen el mismo diseño y paisajismo, sino que utilizan hasta los mismos nombres.

Asimismo, los residentes de urbanizaciones cerradas son gente 'global', es decir, están vinculados con otros países por cuestiones laborales (trabajan en empresas multinacionales) o personales (han vivido en otros países), han viajado y viajan regularmente al extranjero, tienen amistades y familiares que viven en el extranjero e incluso adoptan costumbres extranjeras y consumen productos extranjeros. Podría aplicarse el concepto de 'clases altas the green you always dreamt of, sitting in your garden looking at the mountains." 54 These messages reflect some of the reasons why gated communities are sought as a residential option, as mentioned earlier.

After analyzing the factors that lead people to live in gated communities, it is important to examine the characteristics of their residents which identify them as a specific social group; in addition to their activities, interests, values and the perception of the city they have.

\section{Who are Gated Community Residents?}

Although gated communities have local characteristics, as they meet the needs, interests and preferences of local population, they are part of a global tendency promoted by developers through marketing campaigns. In many cases, a specific design is replicated

54 The first two messages are advertising of gated communities located in Queretaro, Mexico. The third message is an advertising of the real estate group La Vacherie (Mendoza, Argentina) http://elinmobiliario.com/desarrollos/argentina/mendoza/ countries/grupo_dinosaurio_-_mendoza/la_vacherie_-_country_golf_315.html (06/19/2011).

revista invi № 73 / November 2011 / Volume № 26: 17-71 
transnacionales'55, que hace referencia a un grupo que es autónomo espacialmente, es decir, no está atado a una localización espacial y puede moverse de país a país fácilmente debido a sus capacidades profesionales o el tipo de trabajo que realiza, aún cuando pueda preferir la permanencia en un lugar (país o ciudad) geográfico determinado. En general estos grupos, según Weiss, cuentan con más de una nacionalidad, lo que facilita su movilidad a nivel global, o en el caso de poseer sólo una, se trata de una ciudadanía con buena reputación, aceptada por los gobiernos de otros países. En la mayoría de los casos, estas personas han sido educadas en lugares de prestigio nacional y/o internacional y se preocupan porque sus hijos sean educados con hábitos occidentales. Según Svampa ${ }^{56}$, los residentes de urbanizaciones cerradas trabajan mayoritariamente en el sector servicios y/u ocupan posiciones de jerarquía en los organigramas institucionales.

Resulta importante destacar que si bien pueden existir diferencias al interior del grupo aquí llamado 'residentes de urbanizaciones cerradas' en cuanto a intereses, valores, nivel educativo, edad, composición familiar y poder adquisitivo, se lo puede catalogar un grupo relativamente homogéneo cuando es considerado en relación a la estructura social en su totalidad ${ }^{57}$.

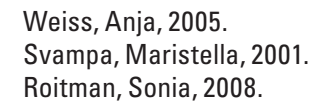

in different countries. Most of Latin American designs are influenced by models from the United States; these not only include the same design and landscape, but also similar names.

But gated community residents are also 'global' people, as they have personal or professional links with other countries, have travelled abroad, have friends or relatives living abroad, adopt foreign customs and consume foreign goods. In this case, the concept of "transnational upper classes" could be applied ${ }^{55}$. This definition refers to a spatially autonomous group that is not bound to a spatial place and can easily move from one country to another thanks to their professional skills and the job they perform, however they may prefer to stay in one geographically determined area (country or city.) According to Weiss, these groups have more than one nationality, which enables them to travel around the world; people with one nationality belong to places that are positively accepted by foreign governments. In most of these cases people are educated in prestigious institutions

55 Weiss, Anja, 2005. 
Por otra parte, es interesante el hecho de que si bien el alto 'poder adquisitivo' sería uno de los elementos más característicos de este grupo, en general cuando sus miembros son consultados respecto a las características de este grupo, este elemento es dejado de lado (o en el caso de ser mencionado, se lo minimiza, por ejemplo se habla de 'medios' y no 'altos' ingresos) y se citan otros elementos como la estructura familiar o el lugar de procedencia. Estefanía (residente de una urbanización cerrada de Querétaro, México) se explaya sobre sus vecinos: “...casi todos son matrimonios jóvenes... ¿qué será? el 70\% yo creo. Son matrimonios jóvenes entre 25 y 45 años, yo creo... la gran mayoría es entre esa edad; los demás son matrimonios ya grandes, ya de edad madura; ...el nivel socioeconómico, igual te digo, todo es medio...". Marianela (de Mendoza) dice que sus vecinos son "principalmente profesionales, jóvenes profesionales en particular, con niños chicos". Por su parte, Juana (quien vive en Querétaro) explicó: “... es gente tranquila... que buscan [sic] mucho esto porque vienen con niños que están libres, corren, andan en bicicleta... gente bien, o sea, bien en el aspecto de, muchos de poder adquisitivo y gente educada". Esteban, quien vive en una urbanización cerrada de Mendoza, expresó: "hay muchas familias que se están formando, muchos chicos y el resto, familias,

ARTíCULO: Distinción social y hábitat residencial en América Latina

/ Sonia Roitman and there is a special interest in receiving western customs. Svampa ${ }^{56}$ highlights that residents of gated communities work in the services area and have important positions in organizational structures.

It is important to point out that, despite the differences regarding interests, values, education, age, family type and income within residents of gated communities, this group of people is homogeneous when compared to the society as a whole ${ }^{57}$.

Furthermore, although income is a characteristic element of residents of gated communities, when asked about their own characteristics, this group does not mention this monetary factor (in some cases this item is minimized), instead, elements such as family structure or the place of origin are mentioned. Estefania (who lives in a gated community in Querétaro) talks about her neighbors: "About $70 \%$ are young married couples; they are between 25 and 45 [years old], the rest are older couples; all of them are of middle socioeconomic level." Marianela (Mendoza)

56 Svampa, Maristella, 2001

57 Roitman, Sonia, 2008. 
matrimonios grandes que se han venido acá por la seguridad, que quieren bueno, quieren estar acá por el resto de su vida, gente amable, atenta, en lo que me ha tocado a mí, no he tenido ningún problema con los vecinos".

Guillermo (residente en una urbanización cerrada de Querétaro) menciona el tema de la procedencia de los residentes como un elemento importante en la elección de este tipo de hábitat residencial: “ ... la gente creo que le gusta el condominio porque viene de fuera y mucha de esa gente de fuera es del D.F. [Distrito Federal o Ciudad de México] o lugares que hay más crimen, entonces quieren llegar a un lugar pues que esté bardeado y tenga su seguridad, por ejemplo ya ahorita, otro ejemplo es del norte que ahí está grueso [difícil] ahorita; hay muchos balazos y gente muerta por lo del narco, que fue ahorita en diciembre [2010], se empezaron a ver muchísimas placas del norte que se vinieron a vivir pa' [sic] acá”.

Sin embargo, algunas personas sí reconocen y hacen referencia al nivel socio-económico alto de la población de las urbanizaciones cerradas. Así, Andrés (residente en Querétaro, México) comentaba sobre la población del lugar donde vive: “...es heterogéneo aunque con algunos puntos comunes que digamos, que serían digamos conductores básicos, familias o individuos de una clase económica de nivel alto, por el tipo de gastos, por el mantenimiento, por lo que implica vivir ahí, con el tipo says that her neighbors are "mainly young professionals with small kids." In addition, Juana (from Querétaro) refers to residents of gated communities as "quiet people who search for a place like this to live because their kids can play freely, ride bikes; they have a good purchasing power and are educated people. Esteban (who lives in a gated community in Mendoza) added: "There are many new families; many kids and then other families who are middle-aged or old couples that moved here for safety reasons; they want to live here for the rest of their lives; they are kind and friendly people, as far as I'm concerned, I have not had any problem with my neighbors."

Guillermo (a gated community resident from Querétaro) talks about the origin of residents as an important element when it comes to choosing this type of housing: "I think people like gated communities because they come from outside [other cities]; also some residents of gated communities come from violent cities so they look for a place that offers security; for instance, things are hard in the north of the country because of drug trafficking, as a result, you start seeing car number plates from the north here. 
de ingresos altos y en general son familias de nivel, de un nivel digamos alto aunque pues bueno, básicamente con vida común, que es el juego, el participar en el club, el golf, todo ese tema, yo así te lo pondría, para decir 'oye, es que hay gente que bueno, hay extranjeros', hay, pues sí, ¿hay un poco de todo, no? Gente que no necesariamente participa en la comunidad de la iglesia que está fuera, que no tiene nada que ver o que ni siquiera tiene sus hijos en el colegio de afuera...". Esta descripción de Andrés pone en evidencia la existencia de cierta heterogeneidad en cuanto a actividades diferentes o procedencias diferentes, pero que si se lo considera en función de 'conductores básicos' (como le llama Andrés), tiene muchos rasgos comunes que los hacen más homogéneos.

En cuanto a las prácticas cotidianas que realizan los residentes de urbanizaciones cerradas, el análisis muestra que existen escasas o nulas posibilidades de interacción social con 'gente diferente'. En el caso de los adultos, sólo aquellos pocos que participan en organizaciones públicas (como asociaciones de mujeres que se dedican a beneficencia) o que realizan actividades sociales o de adoctrinamiento religioso a través de la iglesia católica tienen la posibilidad de interactuar con personas de nivel socioeconómico diferente o intereses diferentes, a excepción del personal de servicio que trabaja en sus viviendas o en la propia urbanización cerrada como personal de seguridad o mantenimiento.
However, there are people that acknowledge and refer to the high socioeconomic level of gated communities residents. Thus, Andrés (from a gated community in Querétaro) said: "Despite being a heterogeneous group, there are some basic conditions such as high socioeconomic level, with high salaries, high purchasing power; living there means high spending levels; this group share a type of life, they play golf or take part in different activities... there are foreigners; there are also people who do not take part in the religious activities of the church located outside the gated community, people who do not have anything to do with the school located outside here and their children are enrolled in a different school." This description reveals a certain level of heterogeneity as far as activities and places of origin are concerned; however, if they are analyzed in relation to these "basic conditions", there are characteristics that homogenize this group of people.

As for daily activities carried out by residents of gated communities, the analysis shows that there are almost no chances of interaction with "different people." In the case of adults, only those who take part in public organizations 
Por otra parte, en el caso de Argentina, con el empobrecimiento de la calidad educativa y la escasez de recursos humanos y financieros en la escuela pública, la educación privada ha crecido exponencialmente. Muchos padres que asistieron a escuelas y universidades públicas y vieron las ventajas de un sistema educativo que facilitaba la integración social, han optado porque sus hijos sean educados en el sistema privado, privilegiando la calidad educativa por sobre la posibilidad de ampliar los horizontes de contacto social. En el caso de los residentes mexicanos, la brecha social ha sido históricamente más importante y más drástica, por lo cual la educación privada es uno más de los elementos que marcan la distinción social. Según del Cueto $^{58}$ quien analiza las prácticas educativas de las niñas y niños que habitan en urbanizaciones cerradas de Buenos Aires (Argentina), la escuela y el barrio eran anteriormente los lugares donde era posible la 'mezcla' de los diferentes grupos sociales y donde los modelos de socialización se basaban en la integración a partir de la diversidad. Según esta autora, ahora la dinámica es la opuesta y la distancia social entre grupos sociales diferentes es mayor, mientras que los círculos sociales son más homogéneos.

Todos los niños y niñas de las familias entrevistadas residentes en urbanizaciones cerradas de Argentina y México asisten a escuelas privadas, laicas

58 Del Cueto, Carla, 2007. (such as social services or charity organizations) or religious activities through the Catholic Church have contact with people from different socioeconomic backgrounds or different interests; with the exception of the interaction with the people who work as cleaners in their houses or security guards and gardeners within the gated community.

Additionally, the decline of education quality and the shortage of human and financial resources have led to the rise of private education in Argentina. A large number of people who studied in state institutions and experienced the advantages of an inclusive educational system have opted now for their children to attend private establishments; in this case, educational quality is privileged over the possibility of increasing social contact. As for Mexico, the social gap has historically been more important and more acute and therefore private education is a defining element of social distinction. Del Cueto ${ }^{58}$, who analyzed the educational practices of children from gated communities in Buenos Aires (Argentina), says that the school and the neighborhood used to be places that

58 Del Cueto, Carla, 2007 
o religiosas. En su mayoría se privilegia la doble jornada escolar y el aprendizaje de idiomas, que van a ser herramientas indispensables para el futuro profesional de estos niños y niñas.

Algunos padres (aun cuando no son la mayoría, y es claramente más evidente que esto sucede más en Argentina que en México, donde los resabios de las ventajas de una 'sociedad integrada' y diversas estrategias de integración social e impulso de la diversidad son aún fuertes entre algunos adultos) manifestaron preocupación sobre la falta de contacto social de sus hijas e hijos con otros grupos sociales. En algunos casos, las escuelas hacen tareas de 'labor social', tal como explica Juana: “... la mayoría de las escuelas en Querétaro hacen labor social, entonces por ejemplo a mis hijos les ha tocado ir a orfanatorios de niños maltratados... y con los viejitos, y les hacen hacer bufandas o comprar ellos de su dinero, comprar ropa interior, pañales para ir a verlos, por ejemplo mis hijos... de la escuela que iban... ir a barrios muy humildes y compartir, en vez de pasar en la escuela, hacer lo de la posada, llevar cada quien pero ir a compartir con ellos, sí, eso trabajan mucho, sobre todo las escuelas sí, sí se trabaja en eso". Pero estas oportunidades de socialización con 'el otro' son muy escasas, quizás solamente una vez al año.

Cuando se analiza cómo se mueven los habitantes de urbanizaciones cerradas en la ciudad, aparecen tres elementos importantes: en general no van al allowed the mix of different social groups; in these institutions, socialization models were based on the social integration of diversity. This author points out that dynamics have dramatically changed and, as homogeneity among social groups increases, the social distance among different groups increases as well. Children from Argentinean and Mexican gated communities attend secular or religious private schools. Most of them take advantage of full-day schooling and the learning of foreign language. These are key elements for their future development as professionals.

Some parents (even if they are not the majority) expressed some are concerned about the lack of social contact of their children and other social groups. This was more evident in Argentina (than in Mexico) where there are still strong remnants of the advantages of an inclusive society and where there are still some strategies for social integration and the encouragement of diversity among some adults. In some cases, some schools carry out social activities, as expressed by Juana: "most of schools in Queretaro are involved in social activities, some kids visit abused children's shelters and they knit scarves or buy goods for 
centro de la ciudad, nunca usan transporte público y consideran la ciudad con una finalidad puramente utilitaria.

La mayoría de los residentes de urbanizaciones cerradas se mueve por diferentes zonas de la ciudad para realizar sus actividades cotidianas, sin embargo tratan de evitar el centro, con excepción de la realización de actividades recreativas (por ejemplo, reunirse con amigos, cenas, ir a bailar). Argumentan que hay mucho tránsito o hay mucha gente y prefieren utilizar otras zonas en lo posible (por ejemplo, otras zonas de comercio). No obstante, es importante notar que hay excepciones, por ejemplo, en el caso de la ciudad de Querétaro, donde el centro histórico es aún considerado un lugar para 'ir a pasear' o caminar un domingo, actividad que es realizada por diversos grupos sociales.

Sobre el uso del centro, Guillermo admitió: "vamos poco, o sea, si hay algo ahora en noviembre fue el día de muertos y a ver altares y llevamos a las niñas, si hay algo específico para las niñas que les pueda gustar, vamos, pero así de 'vamos al centro', si viene alguien a visitar, pero no, tratamos de evadirlo [por el]... tráfico, mucho tráfico, todo el día hay tráfico, estacionarse es una bronca...". Por su parte, Esperanza, quien al igual que Guillermo vive en una urbanización cerrada de Querétaro, señaló que ocasionalmente va al centro histórico: the elderly people; for instance, my children visited deprived neighborhoods and shared food with others, schools are focused on these activities." However, these opportunities of socialization occur just once a year.

There are three elements that emerge when it comes to analyzing the mobility of residents of gated communities: they do not use the city center, do not use public transport and they understand the city from a utilitarian perspective.

Most of gated community residents move around different areas of the city in order to carry out daily activities; however, they try not to go to the downtown unless they perform leisure activities such as meeting with friends, going out for dinner or clubbing. They refer to the city center as a crowded and congested place; this group of people uses other city areas such as alternative shopping areas. But it is important to point out that there are some exceptions; for instance, the historical center of Queretaro is still regarded by different groups as a place to "go for a stroll" on Sundays. 
"cuando vienen visitas siempre vamos al centro de Querétaro... A caminar, a comer... si es gente que no conoce mucho de Querétaro, yo disfruto mucho enseñándoselos".

Varios entrevistados residentes en urbanizaciones cerradas de Mendoza (Argentina) vivían en el centro de la ciudad antes de mudarse al lugar donde viven actualmente. Desde que se fueron del centro, tratan de evitarlo. Carina comentó: “... [Nuestro departamento] estaba en el centro. Entonces [yo] salía con los chicos a tomar algo, bajaba a la peatonal y ahora los chicos se han desacostumbrado al centro, se han desacostumbrado a andar por la calle... Y yo veo a la más grande que anda por la calle un poco temerosa porque se desacostumbró a caminar por la calle San Martín ${ }^{59}$, que para nosotros era lo más común... Y ahora todo eso le parece extraño y eso me parece una contra espantosa de estos barrios [las urbanizaciones cerradas]: la desadaptación de los niños a lo que es la vida común de la calle que hemos vivido todos". Por su parte, Camila dice: "... antes iba más al centro, pero porque vivía en el centro, ahora rara vez voy al centro, va mi marido a veces al centro... no necesito nada de allá... me siento siempre insegura, me molesta el tráfico, me molestan los limpiavidrios, me molesta, no me causa gracia ir al centro, para nada...".

59 San Martín es la calle principal del centro de la ciudad de Mendoza.
As for the use of the city center, Guillermo says: "we rarely go to the city center, this November we went to celebrate the Day of the Dead and visit shrines, we took the girls with us. Sometimes we visited the downtown if the girls want to see something in particular; however, we try to avoid going there, as this is a very congested place in which parking becomes very difficult." In addition, Esperanza (who like Guillermo lives in a gated community in Querétaro) says she goes to the city center from time to time: "If we have guests, we always go downtown to have a walk or eating out, I enjoy showing the city to people who know little about Querétaro."

A large number of those interviewed in Mendoza used to live in the downtown area before moving to gated communities. They try to avoid going to the center of the city, "it [our apartment] was located in the city center. I used to go out for a drink with the children and walk in the street, and now the kids are not used to walk in the streets anymore... I see people that are afraid of walking in the 
Los residentes de urbanizaciones cerradas de Argentina y México entrevistados no utilizan transporte público para realizar sus actividades cotidianas. En el caso de los niños y niñas, sus padres los llevan diariamente en automóvil al colegio. Los adolescentes y jóvenes que aún no tienen licencia de conducir también utilizan a sus padres como choferes, y en algunos casos, también tienen choferes que trabajan para sus familias. Los jóvenes en edad de conducir tienen, en su mayoría y sobre todo en el caso mexicano, un automóvil a su disposición para movilizarse por la ciudad, incluso algunos manifestaron que nunca han utilizado un autobús. Esto también fue mencionado por Rojas ${ }^{60}$ en su investigación sobre adolescentes que viven en urbanizaciones cerradas del Área Metropolitana de Buenos Aires (Argentina), quien ilustraba esta situación con el caso de una chica de 18 años que nunca había utilizado el transporte público. Juana (quien vive en Querétaro) explicó: “...hacemos ronda con una mamá y la mayoría, la mayoría de nenas de la edad de Estefi de 17 años, te hablo de lo que me toca vivir, tiene auto desde los 16, 17 años, o sea, sobre todo la gente que vive acá, por ejemplo compañeras de Estefi la mayoría tiene auto y chicos también... Van a la escuela [en auto], van, vienen, al cine, adonde sea en auto y la mayoría de gente acá, por ejemplo una familia de cinco personas tiene cuatro carros, cuatro autos".

60 Rojas, Patricia, 2007. street as they lost the habit of walking through San Martin Street ${ }^{59}$ that was so common for us. Now all seems strange to them, this is a big disadvantage of gated communities... The ability of children to walk in the street as we used to do it" (Carina.) Camila added: "I used to go downtown because I used to live there, now I rarely go there, my husband sometimes visits the city center... I don't need anything there, I always feel insecure there... I don't like the traffic and the people that clean your windshield, I don't enjoy going to the downtown."

Gated community residents from Querétaro and Mendoza who were interviewed do not use public transport for their daily activities. In the case of children, their parents take them to school by car every day. Young people who do not have a driver license yet use their parents as chauffeurs; in some cases, some of them have their own private family chauffeur. Most young people who are allowed to drive have their own vehicle to move around the city (especially in the Mexican case.) Some youngsters even said they had never taken a

59 San Martin st is the main street of Mendoza's downtown. 
Todos los adultos utilizan el automóvil como medio de transporte. El único transporte público que ocasionalmente algún residente usa es el servicio de radio-taxis, con la excepción de algunas mujeres que no conducen y por lo tanto utilizan este servicio de forma permanente.

Cuando se los consulta por los motivos por los cuales no utilizan transporte público, sus respuestas pueden dividirse en dos grandes grupos: los que dicen que el transporte público es ineficiente e inseguro y aquellos que dicen que se han sentido incómodos porque hay gente 'diferente'. En relación al primer grupo, Carla (residente en una urbanización cerrada de Mendoza, Argentina) detalló su rutina: "Llevo a los chicos a la escuela en auto todos los días. La escuela es en el centro [de la ciudad]. ¡Manejo 120 kilómetros todos los días! Prefiero esto porque así estoy más tranquila. Los podrían secuestrar [a los chicos] si los mandara a la escuela en micro [autobús]". Asimismo, Inés (quien vive en la misma urbanización cerrada que Carla) describió los inconvenientes del uso del transporte público: "suponete si vos te querés venir en ómnibus no es lo más cómodo, tenés por lo menos desde mi casa que es cerca, 6 cuadras o más; si vivís un poco más allá tenés seguro 10 ó 20 cuadras para tomarte un ómnibus, te vas a demorar bastante para ir a cualquier lado... no sé si le resulta a todo el mundo". bus. This was also mentioned by Rojas ${ }^{60}$, who studied teenagers living in gated communities in the Metropolitan Area of Buenos Aires. This author shows the experience of a 18 year old girl who had never used public transport as example of his research. Juana from Querétaro explained: "We take rounds with other mum; and most girls who are the same age as Estefi, who is 17 years old, have a car; for instance, most of Estefi's friends have one. They use cars to go to school, to the movies, to everywhere, most people who live here [in gated communities] have vehicles; for instance, a 5 member family has four cars."

All adults use vehicles as a means of transport. The only public transport they use are radiotaxis; some women who do not drive use this transport on a regular basis.

When asked about the reasons why they do not use public transport, gated community residents are divided into two groups: those who say public transport is inefficient and insecure and those who feel uncomfortable in front of "different people." As for the first group, Carla (who lives in a gated community

60 Rojas, Patricia, 2007. 
Juana (quien es argentina pero ha vivido en México por más de 20 años y por lo tanto comparaba el sistema de transporte público en ambos países) relató: 'el transporte público es lento, van amontonados, todos pegados y este, si la mayoría tiene auto, la mayoría, la gente acá no camina mucho y sí es totalmente diferente [a Argentina], totalmente, y es inseguro... está muy marcada la clase social, o sea, a mí no me importa, yo cuando llegué a vivir acá tomé [el autobús] 6 años, pero te ven diferente, la misma gente humilde te ve diferente, como diciendo 'esta ¿qué hace acá?', ahora por ahí no se nota tanto, tanto, pero sí está dividida, acá [en el barrio] hay gente que jamás ha tomado, por ahí taxi, taxi sí, pero si la misma gente de acá adentro agarra el auto para ir al club [club-house dentro de la misma urbanización cerrada]".

Esperanza, quien es española y ha vivido en México más de 35 años, compartió su experiencia con el uso del transporte público: "tuve episodios muy desagradables... En México, claro, te estoy hablando de hace 36 años, tuve episodios como muy desagradables, muy incómodos y fui entendiendo... O sea, de ir embarazada en el camión [autobús] y decirte el señor de al lado 'qué bonita pancita, yo las hago muy bonitas también'... o el que te da un pellizco en la pompa, o el que te echa un piropo pero no es un piropo, es muy grosero, o el que te roza el busto... yo me negaba a manejar, no quería manejar pero entendí que es parte del sistema, a mis hijos les enseñé a usar el transporte público in Mendoza) talks about her routine: "I use the vehicle to take the children to school, which is located in downtown, by car every day. I drive $120 \mathrm{~km}$ every day! I prefer doing this because I feel more relaxed. If I let them take the bus, they might run the risk of being kidnapped." Additionally Inés, who lives in the same place than Carla, talks about the disadvantages of public transport: "Buses are not comfortable, you have to walk at least six blocks from my home to the bus stop and probably 10 or 20 blocks if you live further up... I'm not sure about the effectiveness of this means of transport."

Juana, who is from Argentina but has been living in Mexico for more than 20 years, compares the public transport system of both countries: "Public transport is slow [in Mexico], people travel in crowded conditions and most of people have vehicles, they are not used to walking; this situation is completely different when compared to the Argentinean case. It is insecure... social classes are welldefined, when I came here, I spent six years taking the bus and people looked at me like saying 'what on earth is she doing here?' Today things are a bit different but there are 
en México; de hecho, el hijo que está soltero y que vive en el D.F. no tiene coche, él no quiere coche y usa transporte público, camión, metro, pecero [tipo de autobús], taxi, camina, pero no quiere coche...".

Tal como explican Juana y Esperanza, en México el uso del transporte público está claramente marcado por la clase social, mientras que en Argentina tal vez debido a que el servicio es de mejor calidad, éste no sólo es utilizado por aquellas personas que no poseen automóvil, sino también por grupos sociales medios que tratan de evitar el tránsito en el centro de la ciudad y los altos costos de estacionamiento y de los combustibles. Los jóvenes y adolescentes argentinos que viven en urbanizaciones cerradas utilizan más el transporte público que las y los mexicanos, para quienes su desplazamiento en la ciudad es más difícil y se sienten atados a sus padres para movilizarse. Por eso utilizan ocasionalmente el transporte público. Fernando, quien vive en Mendoza, reconoce: "voy a todos lados en micro [autobús]... o camino". Julieta (también de Mendoza) agrega: "Y a veces [voy en] colectivo [autobús], a veces me prestan el auto, a veces me pasan a buscar amigas del trabajo y me traen [de vuelta a mi casa]...". Alfonso (otro residente mendocino) se explaya sobre la situación de sus tres hijos adolescentes: “. . los llevamos nosotros a la escuela, los van a buscar los abuelos... nos rebuscamos los horarios pero, la mayor en algunas oportunidades si ha ido a visitar una amiga en colectivo [autobús]". still social divisions. There are people who only take taxis and there are others that use vehicles to go to the club [club-house located within gated communities.]"

Likewise, Esperanza, who is from Spain and has been living in Mexico for 35 years, gives her opinion regarding public transport: "I have experienced uncomfortable situations, I remember when I was pregnant and a man said to me 'what a beautiful belly, I make beautiful bellies too.' Sometimes I got my bottom pinched, received rude compliments or had my breasts touched, I did not want to drive but then I understood this was how things worked here; however, I taught my children how to use public transport, in fact, my son lives in the Federal District and do not have a vehicle (he does not want to have one), he uses public transport... bus, metro, taxi... walking... he doesn't want to have a car"

As it was pointed out by Juana and Esperanza, while in Mexico the use of public transport is determined by social classes, the Argentinean case shows that maybe, because of the better quality of the service, public transport is not only used by those who do not have a car, 
Debido al cierre perimetral de las urbanizaciones cerradas, el transporte público no está autorizado a entrar dentro de ellas. Algunas urbanizaciones (pero muy pocas) cuentan con un servicio de transporte privado que traslada a residentes y empleados dentro del mismo barrio o hasta la entrada principal y en casos excepcionales, algunas urbanizaciones poseen un servicio privado que lleva a sus residentes desde el barrio hasta el centro de la ciudad. Samuel, residente de una urbanización cerrada de Mendoza y miembro de su comisión de vecinos, explicó: "por razones de seguridad sería impensable tener transporte público dentro del barrio. No podríamos controlar los micros [autobuses] que entran y salen y los pasajeros".

El tercer elemento que aparece al analizar la vida cotidiana de los residentes de urbanizaciones cerradas es la forma en la que perciben la ciudad, la cual es vista desde una perspectiva utilitarista y no social. En la mayoría de los casos, la ciudad es -para los entrevistados- asociada a la satisfacción de necesidades básicas: vivienda, trabajo, salud, educación, esparcimiento y, en consecuencia, relacionada con la existencia de ciertos servicios y no como un espacio para promover la integración y diversidad social. En este sentido, Arizaga ${ }^{61}$ advierte sobre un "cambio cualitativo en cuanto al uso del espacio", en donde se deja atrás "el paradigma de la ciudad como lugar de intercambio

61 Arizaga, Cecilia, 2003: 8. but also by middle-class groups who try to avoid the traffic of the downtown and the high costs of parking and fuel. Argentinean youngsters who live in gated communities use public transport more regularly than Mexican people. It is difficult for them to move around the city and depend on their parents to do so, this is why they use this kind of transport. Fernando, who lives in a gated community in Mendoza, comments: "I either use the bus or walk", Julieta (also from Mendoza) adds: "Sometimes I travel by bus, sometimes I use the car or my friends come to pick me up to go to work." Alfonso (another Mendocinean resident) thinks about the situation of his three children: "We take them to school and their grandparents take them home, we try to organize the schedules... sometimes the eldest one uses the bus to visit her friends."

Since gated communities are surrounded places, public transport cannot go inside. Some of these gated communities (but only a few) have their own private transport system that takes residents and workers within the same development or to the main gate; in some cases, these services take residents to the city center. 
con múltiples 'otros', en tanto 'ciudad abierta', más cercana a un modelo europeo".

A su vez, Svampa ${ }^{62}$ también habla de la crisis de un modelo de ciudad 'abierta' basado en el espacio público que garantizaba la integración social, la interdependencia y la interacción con la diferencia. Según esta autora, ahora se trata de un modelo de 'ciudad cerrada' siguiendo el modelo de Estados Unidos, donde se privilegia la ciudadanía privada. En este sentido, y siguiendo a Svampa, parecería que la ciudad deja de lado su función social y retiene solamente las funciones económicas y culturales, ya que continúa siendo el lugar donde se desarrollan mayoritariamente las actividades culturales (aunque a medida en que la periferia se especializa, también estas actividades van trasladándose fuera de las áreas centrales). Según Bourdin, 63 se trata del paso de entender la ciudad como un orden social a partir de la organización espacial, a entenderla como un 'sistema de ofertas': ofertas de actividades profesionales, de empleos, de servicios, de productos, de relaciones y de sentidos.

Paulina, quien vive en una urbanización cerrada de Querétaro, opina: "Pues yo creo que.. para hacer una ciudad necesitas tener muchos servicios, muchos, pues servicios, porque tienes que tener restaurantes, tiendas, etcétera, etcétera, clubs, colonias [barrios], no es como en un lugar muy

62 Svampa, Maristella, 2001

63 Bourdin, Alain, 2007
Samuel, resident of a gated community located in Mendoza and member of the residents' association said: "For security reasons, it would be unthinkable to allow public transport systems in the neighborhood; we would not be able to control buses and passengers."

The way gated community residents perceive the city is another is another element that emerges when the everyday life this group of people is analyzed. The city is understood in a utilitarian way, and not as a social entity. In most of cases, the city is associated with the satisfaction of basic needs such as housing, work, health, education and leisure and therefore a place where some services are provided. Thus the city is not seen as a place aimed at promoting integration and social diversity. In this sense, Arizaga ${ }^{61}$ foresees a "qualitative change of space use", which replaces the paradigm of the city as a place where people interact with 'other' people based on the European concept of the 'open' city.

Svampa ${ }^{62}$ also mentions the crisis of this "open" city model, which was based on the

61 Arizaga, Cecilia, 2003:8.

62 Svampa, Maristella, 2001. 
chiquito que no tienes ese tipo de servicios... supers [supermercados]... la ciudad es un lugar para, pues más bien para divertirse, para tener conocimiento porque tienen más lugares de cultura, porque tienen, es que los espacios son diferentes, o sea, son más, podrás tener cines, teatros, escuelas mejores, universidades". Bernardo, quien vive en otra urbanización cerrada de Querétaro, comentó: "la ciudad es un centro poblacional, que debe de contar con, o sea, está complementada con todo, tiene que tener lugares donde la gente trabaje, lugares donde la gente estudie, lugares donde la gente tenga recreación, que pueden ser parques, cines, teatros, auditorios, estadios, todo ese tipo de cosas..”. A su vez, Jerónimo (residente en otra urbanización de Querétaro) dijo que una ciudad debe contar "idealmente, pues con una infraestructura más moderna y más acorde con la gente que vive ahí, por ejemplo aquí el transporte público pues es muy, sobre todo el masivo es muy deficiente, las vialidades estaban muy bien, hasta hace, cuántos años, diez años, en que empezó a crecer más y el gobierno que entró no hizo vialidades nuevas, entonces se empezó a congestionar el tráfico, ya se están empezando a hacer esas vialidades...".

Muy pocos entrevistados se refirieron al 'aspecto social' de las ciudades. Andrés fue uno de estos pocos: "Para mí, la ciudad es como un centro neurálgico, es un órgano vivo que por lo mismo pues idea of the public space that allowed for social integration, interdependence and interaction among different people. According to this author, the current model is based on the American concept of the 'closed' city, in which private citizenship prevails. It seems that the city is giving away its social function and is focused on economic and cultural aspects, as the city is still the place where cultural activities are carried out, even if these initiatives are flourishing beyond central areas. According to Bourdin $^{63}$, this is the process of moving from understanding the city as a social order based on the spatial organization, to understand it as a 'supply system' related to the supply of professional activities, jobs, services, products, relationships and meanings.

Paulina, who lives in a gated community in Querétaro said: "I think you need a large number of services such as restaurants, shops, clubs and neighborhoods to build a city; unlike those very small places where you don't have such services, supers [supermarkets]...the city is a place to have fun and build knowledge, as there are spaces focused on cultural activities; it is possible to have access

63 Bourdin, Alain, 2007. 
te digo, me pelearía un poco en ese concepto de guetos, de apartheids, que los vuelven aislados, la ciudad tiene que ser, bueno no tiene que ser, sino la ciudad es un centro de convivencia, yo lo que creo un poco ahí, quizás dirás es un poco aspiracional, un poco ilógico, pero es que yo creo que lo que debe de ser es eso, un centro orgánico de convivencia, armónico, donde haya una cohesión social que permita satisfacer a todo el mundo sus necesidades". Ante la pregunta de si esta situación se da en ciudades mexicanas, Andrés respondió: "Yo creo que sí se puede dar, quizás no lo sé si en Querétaro, pero sí debe de haber... por ejemplo, hay muchas ciudades en México e incluso en la misma Ciudad de México en donde conviven personas muy distintas, grupos muy disímiles en territorios muy cercanos, por ejemplo la colonia de Las Lomas, me quiero referir a la Ciudad de México, porque la Ciudad de México es una ciudad vibrante, monstruosa, pero al mismo tiempo con una vida monumental, o sea, la Ciudad de México es milagrosa a veces, yo creo cómo vive y tú ves que en la Ciudad de México hay colonias y barrios que conviven con otros que son social y económicamente muy distintos, pero sin embargo interactúan y eso hace a la Ciudad de México, por ejemplo, interesante, ahora con graves problemas, porque también pues el tema urbano, el transporte... el tema aquí en México es también de nivel sociocultural, o sea, el país está muy marcado en eso, tiene muchas diferencias, pero sin embargo, to cinemas, theatres and better schools and universities." Bernardo (also from Querétaro) believes: "The city is a population center: places for people to work, places for people to study, places where people can have fun, these can be parks, cinemas, theatres and conference halls, stadiums, all those things" (Bernardo, Queretaro.) Jerónimo (who lives in another gated community from Querétaro) thinks that a city "should ideally have modern infrastructure that suits the needs of residents, for instance, public transport, especially the massive one, which is of poor quality... and all roads were in good condition; ten years ago, but when the city began to grow and since the government did not build new roads, traffic became congested; now there are new roads under construction.

Very few respondents commented on the 'social aspect' of cities. Andrés was one of those few ones: "For me, the city is like a hub, it is like a living organ... the city is a center of coexistence... I reject the ideas of ghettos and apartheids... Maybe it is a bit idealistic but it is what I believe it should be... an organic living center where there is a harmonious social cohesion that allows everyone to satisfy their needs." When 
creo que se han dado ejemplos interesantes de grandes comunidades que conviven y finalmente van permeando, están al lado de otras comunidades, yo creo que a eso tendríamos que aspirar porque forma parte de, o sea, la ciudad debe aspirar a eso, es como grandes ciudades, por ejemplo, no sé, San Francisco, que supo involucrar a la comunidad hindú, a la comunidad china, a la comunidad latina, a la comunidad gay, o sea, son ciudades abiertas y que las hace increíblemente interesantes y por lo mismo son ciudades muy atractivas donde tú puedes encontrar donde vivir y todos conviven...yo creo que las ciudades si son integradas, si tienen un nivel de, o sea, si aspiran a integrar no a segregar, deben inspirar a ser eso, porque todos pueden convivir...".

Este último largo comentario reivindica el papel de la ciudad como lugar de integración social y como lugar al que muchos, aún aquellos que habitan en urbanizaciones cerradas, aspiran. Así se podría referir a lo que Frug ${ }^{64}$ llama 'construcción de comunidad', no en el sentido de un grupo social que comparte características y valores comunes, sino usando el concepto de comunidad en relación al 'tipo ideal de vida urbana' que desarrolla Iris Young ${ }^{65}$. Este último concepto implica el desarrollo de relaciones sociales entre personas desconocidas que están juntas y que por consiguiente

64 FRUG, Gerald, 1999.

65 Young, Iris, 1990. asked if this situation occurs in Mexican cities, Andrés answered: "I think it might be found, maybe not in Querétaro... for example there are many cities in Mexico and even Mexico City itself where diverse people live together, different groups live in nearby territories... you see in Mexico City neighborhoods that coexist with others which are socially and economically very different, yet they interact and that makes the City of Mexico, for example, interesting, now with serious problems, like public transport... here in Mexico it is also an issue of socio-cultural differences, the country has starched differences, but nevertheless I think you have interesting examples of large communities who live (and will eventually permeate to other areas) next to other communities; I think we should aspire to that because it is part of what a city must aspire to..."

This last comment reinforces the role of the city as a place of social integration and the place that a large number of people, even gated community residents, aspire to live in. This is what Frug ${ }^{64}$ calls "community construction"; this concept is not related to social groups

64 Frug, Gerald, 1999. 
comparten ciertos problemas e intereses comunes y no necesariamente desarrollan mutua identificación y reciprocidad.

Finalmente, es relevante mencionar que, tal como indica David Harvey ${ }^{66}$, la forma en que vivimos la ciudad cotidianamente influye en cómo nos situamos en el mundo, y cómo pensamos y actuamos políticamente dentro de él.

\section{Conclusiones}

El presente artículo ha puesto en evidencia el desarrollo de las urbanizaciones cerradas en América Latina, considerando cuáles son los elementos que caracterizan a este tipo de hábitat residencial destinado a grupos sociales medio-altos y altos y que lo hacen ser un elemento más de distinción social y de estatus para grupos e individuos. Su desarrollo plasma un modelo social que privilegia la homogeneidad social y el contacto sólo con iguales, en ámbitos social y espacialmente reducidos. Influidos por las campañas publicitarias de las empresas desarrolladoras de urbanizaciones cerradas ciertos individuos ven a este tipo residencial como un elemento más de consumo que permite posicionarse socialmente y permite explicitar su pertenencia a cierto grupo social. Asimismo, existe una 'lucha

66 Harvey, David, 2006. sharing characteristics and values, but to the ideal concept of urban life developed by Yris Young ${ }^{65}$. Such concept implies social relationship among different people who, despite sharing problems and interests, do not develop identification and reciprocity.

As David Harvey ${ }^{66}$ points out, the way we live the city determines our position in the world and how we think and act within it.

\section{Conclusion}

This article revealed the development and characteristics of gated communities in Latin America, as well as the reasons why this type of housing, which is aimed at upper and uppermiddle income groups, became an element of social distinction and status. The development of gated communities shapes a social model that favors social homogeneity and contact among equals within a reduced social and spatial environment. Influenced by marketing campaigns, some peopleidentify this residential type as a consumption item that ensures social

65 Young, Iris, 1990.

66 Harvey, David, 2006 
por pertenecer' en donde al igual que el tipo de escuela o universidad a la que se asiste, los amigos con que se cuenta, el lugar de residencia actúa como uno de los elementos más significativos para posicionar socialmente a una familia o individuo. Los residentes de urbanizaciones cerradas no sólo tienen características demográficas y/o sociales similares que los hacen un grupo social homogéneo en relación al conjunto de la sociedad, sino que tienen prácticas y valores similares como la no utilización del centro histórico ni del transporte público urbano, la asistencia a establecimientos educativos privados y la concepción utilitarista de la ciudad como una entidad importante en cuanto que provee de bienes y servicios a su población. La ciudad deja de lado su rol social y retiene sólo las funciones económicas.

El riesgo del desarrollo de urbanizaciones cerradas se relaciona con su no sustentabilidad en los ámbitos ambientales, urbanos y sociales, y con el tipo de contribución que las mismas pueden hacer a la ciudad en genera ${ }^{67}$ y a la sociabilidad actual y futura al crear espacios de uso restringido que impiden la integración social con la diversidad. El abandono de ciertas prácticas sociales (como el uso del centro de la ciudad) o la no realización de otras prácticas urbanas (tales como el uso de transporte público) que son esperadas en ciudades

67 Al respecto se puede ver el artículo de Roitman, Sonia y Phelps, Nicholas, 2011. status and the sense of belonging to a specific social group. Likewise, there is a "struggle to belong" to a particular social group, in which factors such as education, friendships and the place of residence are elements that determine social status. Residents of gated communities, apart from sharing demographical and social characteristics, thus becoming a socially homogeneous group, have similar practices and values such as the reluctance to use the city center or public transport, the enrolment in private schools sports centers and the utilitarian conception of the city as far as the supply of goods and services are concerned. The city loses its social function and only focuses on economic aspects.

The risk of the development of gated communities is related to their environmental, urban and social unsustainability and their contribution to the city ${ }^{67}$ and social relationships with the creation of restricted spaces which hinder social integration and diversity. The withdrawal from social activities (such as the use of the downtown) or other urban practices (use of public transport)

67 See Roitman, Sonia and Phelps, Nicholas, 2011. 
socialmente sustentables por parte de ciertos grupos sociales, hace que los mismos pierdan interés en áreas de la ciudad o servicios que aun cuando deberían servir para satisfacer las necesidades de toda la sociedad, ya no lo hacen. Esto es debido a que aquellos que pueden satisfacer sus necesidades de otra forma, pueden acceder a servicios privados, y pueden desentenderse del estado del espacio urbano público y de la calidad de los servicios públicos, como es el caso del transporte, simplemente dejan de interesarse por 'la cosa pública'. Esto incrementa la brecha social y los imaginarios de 'rico igual a privado' y 'pobre igual a público'.

La sustentabilidad urbana, un mejor acceso a servicios y el mejoramiento de la calidad del espacio urbano son elementos que deben considerarse si se busca reducir la desigualdad social urbana en América Latina, tal como se manifestó al inicio de este artículo. La mejora macroeconómica es sólo un aspecto para reducir la brecha social, pero es necesario también que existan políticas urbanas que contemplen no sólo la mejora del transporte público y el mantenimiento de los espacios públicos urbanos para que exista un acceso más igualitario a la ciudad y a las ventajas que ofrece la vida en la ciudad, sino también la creación de eventos, actividades y ámbitos que favorezcan una vuelta a la idea de la ciudad como lugar de integración social con la diversidad. that are anticipated in socially sustainable cities create lack of interest in services that used to meet the needs of society. Some people can satisfy their needs in a different way because they have access to private services and therefore there is no interest in the condition of public urban space and the quality of public services, such as transport. This situation increases the social gap and reinforces the "rich-private" and "poor-public" conceptualizations.

Urban sustainability, better access to services and the improvement of urban space are elements that should be taken into consideration to reduce urban social inequality in Latin America, as mentioned in the beginning of this article. Macroeconomic improvement is an aspect that contributes to reduce social gaps; however, there is also a need for urban policies aimed at improving public transport and maintaining public urban spaces in order to ensure equal access to the city and its activities; in this way, the city may be again a place promoting social integration and diversity. 


\section{Bibliografía / Bibliography}

ÁLVAREZ, María José. Golden ghettoes: golden communities and class residential segregation in Montevideo, Uruguay. Rep. No. 02/2005, Research and Training Network Urban Europe. 2005.

ARIZAGA, Cecilia. El mito de comunidad en la ciudad mundializada. Estilos de vida y nuevas clases medias en urbanizaciones cerradas. Buenos Aires, El cielo por asalto. 2005.

ARIZAGA, Cecilia. Nuevas urbanizaciones cerradas en los noventa: representaciones del suburbio en sectores medios. Buenos Aires, Instituto de Investigaciones Gino Germani, Universidad Nacional de Buenos Aires. [En línea]. Facultad de Ciencias Sociales UBA. Junio 2003. Disponible en: http:// webiigg.sociales.uba.ar/iigg/textos/documentos/ ji4.pdf

BAIRES, Sonia. La nueva segregación urbana en América Latina: Los barrios cerrados en el Área Metropolitana de San Salvador, El Salvador. San Salvador, El Salvador, Universidad Centroamericana José Simeón Cañas. 2003.

BARCENA, Alicia. La hora de la igualdad. Panorama de la gestión pública en América Latina. [En línea]. Seminario de Política Fiscal CEPAL. 18 de enero de 2011. [Fecha de consulta: 5 de marzo de 2011]. Disponible en: http://www.eclac.cl/noticias/paginas/8/33638/110118_versionFINALFINALseminariofiscal2011.pdf
BLAKELY, Edward J. y SNYDER, Mary Gail. Fortress America. Gated communities in the United States. Washington and Cambridge, Mass, Brookings Institution Press and Lincoln Institute of Land Policy, 1997.

BORJA, Jordi. Ciudad y planificación: La urbanística para las ciudades de América Latina. En BALBO, Marcello, JORDAN, Ricardo, comp., SIMIONI, Daniela, comp. La ciudad inclusiva. Santiago de Chile, CEPAL. 2003. p. 81-104. ISBN 92-1322259-9.

BORSDORF, Axel e HIDALG0, Rodrigo. Formas tempranas de exclusión residencial y el modelo de la ciudad cerrada en América Latina. El caso de Santiago. [En línea]. Revista de Geografía Norte Grande. (32): 21-37, 2004. ISSN 0379-8682. Disponible en: http://redalyc.uaemex.mx/src/inicio/ ArtPdfRed.jsp?iCve=30003202

BORSDORF, Axel. Barrios cerrados en Santiago de Chile, Quito y Lima: tendencias de la segregación socio-espacial en capitales andinas. En: CABRALES BARAJAS, Luis Felipe, coord. Latinoamérica: países abiertos, ciudades cerradas. Guadalajara, México, Universidad de Guadalajara UNESCO. 2002. p. 581-610.

BORSDORF, Axel. Cómo modelar el desarrollo y la dinámica de la ciudad latinoamericana. [En línea]. EURE. 29(86): 37-49, 2003. ISSN 0250-7161. Disponible en: http://www.scielo.cl/scielo.php? pid=S0250$71612003008600002 \&$ script=sci_abstract 
BORSDORF, Axel, HIDALGO, Rodrigo y SÁNCHEZ, Ricardo. A new model of urban development in Latin America: the gated communities and fenced cities in the Metropolitan areas of Santiago de Chile and Valparaíso. [En línea]. Cities. 24(5): 365-378. 2007. ISSN 0264-2751. Disponible en http://dx.doi.org/10.1016/j.cities.2007.04.002

BOURDIN, Alain. La metrópoli de los individuos. México, Universidad Iberoamericana de Puebla. 2007.

BRACHO DE MACHADO, Diana, FARIA LARRAZABALI, Carmen y PAREDES DE LÓPEZ, María. Dos realidades: dos maneras de habitar conviven hoy en la ciudad. [Enlínea]. RevistaINVI. 22(60):37-58,2007. ISSN: 0718-1299. Disponible en: http://revistainvi.uchile.cl/index.php/INVI/article/view/280

CABRALES BARAJAS, Luis Felipe y CANOSA ZAMORA, Elio. Segregación residencial y fragmentación urbana: los fraccionamientos cerrados en Guadalajara. [En línea]. Espiral, 7(20): 223-253. 2001. ISSN 1665-0565 Disponible en: http://redalyc.uaemex.mx/src/inicio/ArtPdfRed. jsp?iCve $=13802008$.

CALDEIRA, Teresa. City of walls. Crime, segregation and citizenship in São Paulo. California, University of California Press. 2000. ISBN 9780520221437.

CASTELLS, Manuel. La sociología urbana en el siglo XXI. En: SUSSER, Ida, ed. La sociología urbana de Manuel Castells. Madrid, Alianza. 2001.

CEPAL. Panorama social de América Latina 2010. Santiago de Chile, CEPAL. 2010.
COY, Martin y POHLER, Martin. Gated communities in Latin American Megacities: case studies in Brazil and Argentina. [En línea]. Environment and Planning B: Planning and Design. 29(3): 355-370. 2002. ISSN 0265-8135. Disponible en: http://www.envplan.com/abstract.cgi?id=b2772

DE LIMA RAMIRES, J. C. y RIBEIRO SOARES, B. Os condomínios horizontais fechados em cidades médias brasileiras. En: CABRALES BARAJAS, Luis Felipe, coord. Latinoamérica: países abiertos, ciudades cerradas. Guadalajara, México, Universidad de Guadalajara UNESCO. 2002. p. 373-396.

DEL CUETO, Carla. Los únicos privilegiados. Estrategias educativas de familias residentes en countries y barrios cerrados. Buenos Aires, Prometeo. 2007. ISBN: 9875741434.

DUHAU, Emilio y GIGLIA, Ángela. Las reglas del desorden: habitar la metrópoli. México, Siglo XXI. 2008. ISBN 9682327601

ENRíQUEZ ACOSTA, Jesús A. Ciudades de muros. Los fraccionamientos cerrados en la frontera noroeste de México. [En línea]. Scripta Nova. 11(230), enero 2007. ISSN 1138-9788. Disponible en: http:// www.ub.edu/geocrit/sn/sn-230.htm.

FRUG, Gerald E. City making: building communities without building walls. New Jersey, Princeton University Press. 1999. ISBN 9781400823345.

\section{GERAIGES DE LEMOS, Amalia, CAPUANO SCARIATO,} Francisco y PÉREZ MACHADO, Reinaldo. O retorno à cidade medieval: os condomínios fechados da metrópole paulista. En: CABRALES BARAJAS, 
Luis Felipe, coord. Latinoamérica: países abiertos, ciudades cerradas. Guadalajara, México, Universidad de Guadalajara UNESCO. 2002. p. 217-235.

HARVEY, David. The political economy of public space. En: LOW, Setha, ed. y SMITH, Neil, ed. The politics of public space. New York, Routledge. 2006. ISBN 978-0415951395. p. 17-34.

HELSEY, Robert W. y STRANGE, William C. Gated communities and the economic geography of crime. [En línea]. Journal of Urban Economics. 46(1): 80-105. 1999. ISSN: 00941190 Disponible en: http://dx.doi.org/10.1006/juec.1998.2114

LUNGO, Mario y BAIRES, Sonia. Socio-spatial segregation and urban land regulation in Latin American cities. En: International Seminar on Segregation in the City (Cambridge, MA, USA. July 25-28, 2001). Lincoln Institute of Land Policy.

MARCUSE, Peter. Cities in Quarters. En: BRIDGE, Gary, ed. y WATSON, Sophie, ed. A companion to the city. Oxford, Blackwell. 2003. p. 270-281. ISBN 9780631235781.

ORTIZ-GÓMEZ, Andrés. Urban planning and the rationale of the market: the elimination of the intermediate urban level in Bogotá. En: SETER, Roger, ed. y WHITE, Rodney, ed. Planning in cities. Sustainability and growth in the developing world. London, ITDG. 2001. p. 71-92. ISBN 1853395439.

PLOGER, Jörg. Practices of socio-spatial control in the marginal neighbourhoods of Lima, Perú. Trialog. 89(2): 32-36. 2006. ISSN 0724-6234.
RODRIGUES SOARES, Paulo R. Fragmentación y segregación espacial en ciudades no metropolitanas: las periferias urbanas del sur de Brasil. En: CABRALES BARAJAS, Luis Felipe, coord. Latinoamérica: países abiertos, ciudades cerradas. Guadalajara, México, Universidad de Guadalajara UNESCO. 2002. p. 549-580.

RODRIGUES, Silvia. Loteamentos fechados e condomínios residenciais em Säo José do Rio Preto. Campinas, Brasil, Pontificia Universidade Católica de Campinas. 2006.

RODRÍGUEZ CHUMILLAS, Isabel y MOLLA RUIZ-GÓMEZ, Manuel. Urbanizaciones cerradas en Puebla y Toluca. En: CABRALES BARAJAS, Luis Felipe, coord. Latinoamérica: países abiertos, ciudades cerradas. Guadalajara, México, Universidad de Guadalajara UNESCO. 2002. p. 511-548.

ROITMAN, Sonia y PHELPS, Nicholas. Do gates negate the city? Gated communities' contribution to the urbanisation of suburbia in Pilar, Argentina. [En línea]. Urban Studies. (in press, published on line 31 March 2011). 2011. ISSN: 1360-063X. Disponible en: 10.1177/0042098010397395

ROITMAN, Sonia. Urban social group segregation: a gated community in Mendoza, Argentina. Tesis doctoral, University College London. 2008.

ROITMAN, Sonia. Urbanizaciones cerradas: estado de la cuestión hoy y propuesta teórica. [En línea]. Norte Grande. (32): 5-19, 2004. ISSN 07183402. Disponible en: http://redalyc.uaemex.mx/ pdf/300/30003201.pdf 
ROJAS, Patricia. Mundo Privado. Historias de vida en countries, barrios y ciudades cerradas. Buenos Aires, Planeta. 2007.

SASSEN, Saskia. The Global City. Princeton University Press. 1991.

SVAMPA, Maristella. Los que ganaron. La vida en los countries y barrios privados. Biblos, Buenos Aires. 2001.

TORRES, Horacio. Procesos recientes de fragmentación socioespacial en Buenos Aires: la suburbanización de las élites. En: Seminario de investigación urbana "El nuevo milenio y lo urbano". Buenos Aires, Instituto Gino Germani UBA. 1998.
WEBSTER, Chris. Gated cities of tomorrow. Town PlanningReview. 72(2): 149-169.2001.ISSN:0041-0020.

WEISS, Anja. The transnationalization of social inequality: conceptualizing social positions on a world scale. Current Sociology. 53(4): 707-728, 2005. ISSN 1461-7064, doi 10.1177/0011392105052722

WILSON-DOENGES, Georgina. An exploration of sense of community and fear of crime in gated communities. Environment and Behavior. 32(5): 597-611. 2000. ISSN 1552-390X. doi $10.1177 / 0011392105052722$

YOUNG, Iris. Justice and the politics of difference. New Jersey, Princeton University Press. 1990. 